\section{Una aproximación a las técnicas constructivas de la Alta Edad Media en la Península Ibérica. Entre visigodos y omeyas ${ }^{1}$}

\author{
Luis Caballero Zoreda, M. a Ángeles Utrero Agudo \\ IH. CSIC. Madrid
}

\begin{abstract}
Resumen
El estudio de la cultura arquitectónica alto medieval de la Península Ibérica se encuentra en un momento de renovación y contrastación caracterizado por la aplicación del método arqueológico. Especialmente, la estratigrafía permite abordar el estudio de las técnicas constructivas y otorgarlas un nuevo valor como potencial elemento diferenciador entre las distintas series arquitectónicas. Así se convierte en una de las claves para comprender las singularidades y las diferencias de las arquitecturas tardo antigua y alto medieval.
\end{abstract}

Palabras clave: Técnicas constructivas, arquitectura hispánica, tarda antigüedad, alto medievo. Madera, piedra, reutilización, material cerámico. Andamios. Aparejos. Siglos VIII-XI

\section{Abstract \\ The study of early medieval architecture of the Iberian Peninsula is in a state of change and renewal, thanks to the application of archaeological methods. \\ In particular, stratigraphy provides a way of analysing construction techniques, giving these new value as a potential means of distinguishing between different groups of buildings. Thus stratigraphy has become one of the keys to understanding the characteristics of, and the differents between, early medieval architecture and the architecture of late antiquity.}

Key words: Construction techniques, Hispanic architecture, late antiquity, early medieval, wood, stone, ceramic building material, scaffolding, masonry, 8 th-11th centuries

\footnotetext{
${ }^{1}$ El presente texto ha sido redactado y reccibido en 2003. Gran parte de los resultados que se presentan aquí derivan de la puesta en marcha de distintos proyectos de investigación dedicados al estudio de la cultura arquitectónica del alto medievo hispano, entre ellos Teoría y práctica de la cronología histórica (investigador principal, Fernán AlONSO MATHÍAS; BHA 2000-1211-C02) y Arqueología de la Arquitectura Alto Medieval en Extremadura, Asturias y Portugal (investigador principal, Luis CABALLERO ZOREDA; BHA 2003-02086).
}

INTRODUCCIÓN. LA TÉCNICA CONSTRUCTIVA DE LA ARQUITECTURA EN PIEDRA ALTO MEDIEVAL

Este trabajo pretende ser un acercamiento a la sistematización de las técnicas constructivas en piedra del alto medievo peninsular, periodo cuyos límites situamos entre los siglos VIII y XI y que se debate ahora entre dos modelos explicativos, lo que impide por el momento efectuar una síntesis definitiva. La diferencia entre ambos modelos radica en la distinta valoración de la influencia del arte andalusí en la Península con la llegada del mundo islámico a partir del 711. Para el modelo tradicional, el arte peninsular no se vería afectado por los nuevos elementos orientales, sino que bebería de la tradición tardorromana y visigoda hasta el siglo XI: lo asturiano, lo mozárabe y, paralelamente, lo andalusí, expuestos como grupos evolutivos cerrados y sucesivos temporalmente, deberían su originalidad a la creación artística local de los siglos VI/VII, aunque con cierto influjo bizantino (PALOL 1967 y SCHLUnK y HaUsChILd 1978). Por el contrario, según el nuevo modelo (CABALLERO 1994/95 y REAL 1995), los sucesos iniciados en el s. VIII se traducirían en un cambio técnico y artístico. Los elementos omeyas influirían en lo asturiano y lo mozárabe y lo considerado visigodo del s. VII presentaría una serie de características que impedirían afirmar fechas tan tempranas, pues requerirían la influencia andalusí para explicar sus peculiaridades, lo que retrasaría necesariamente su cronología a un momento posterior al 711.

Pero el nuevo modelo, surgido con la intención inicial de responder a las contradicciones del primero, no implica un mero cambio de fechas. Constituye además una explicación histórica alternativa y una renovación del análisis metodológico y crítico de las fuentes y contenidos tradicionales. Las contradicciones del modelo tradicional y los interrogantes que planteaba han incentivado el avance de la metodología arqueológica, ahogada hasta ahora por la interpretación de las fuentes escritas y estilísticas y reducida a una escasa práctica excavadora.

El estudio de las técnicas constructivas ha funcionado como otro de los argumentos de diferenciación temporal y cultural de la arquitectura, pero se ha efectuado desde una óptica descriptiva definida por cronologías apriorísticas (HaUSCHILD 1972, 1982 y 1996; KINGSLEY 1979; Caballero 1991; ARBEITER 1995 y 1996). La renovación del análisis de la arquitectura gracias a la aplicación de la metodología arqueológica (estratigrafía de paramentos) ha introducido un cambio significativo. El edificio no se comprende como un bloque unitario, sino como un yacimiento sometido a cambios materializados en diferentes técnicas que significan etapas constructivas y/o cronológicas, cuya ordenación se establece por la estratigrafía muraria. Lo mismo se puede decir de los elementos considerados hasta ahora 


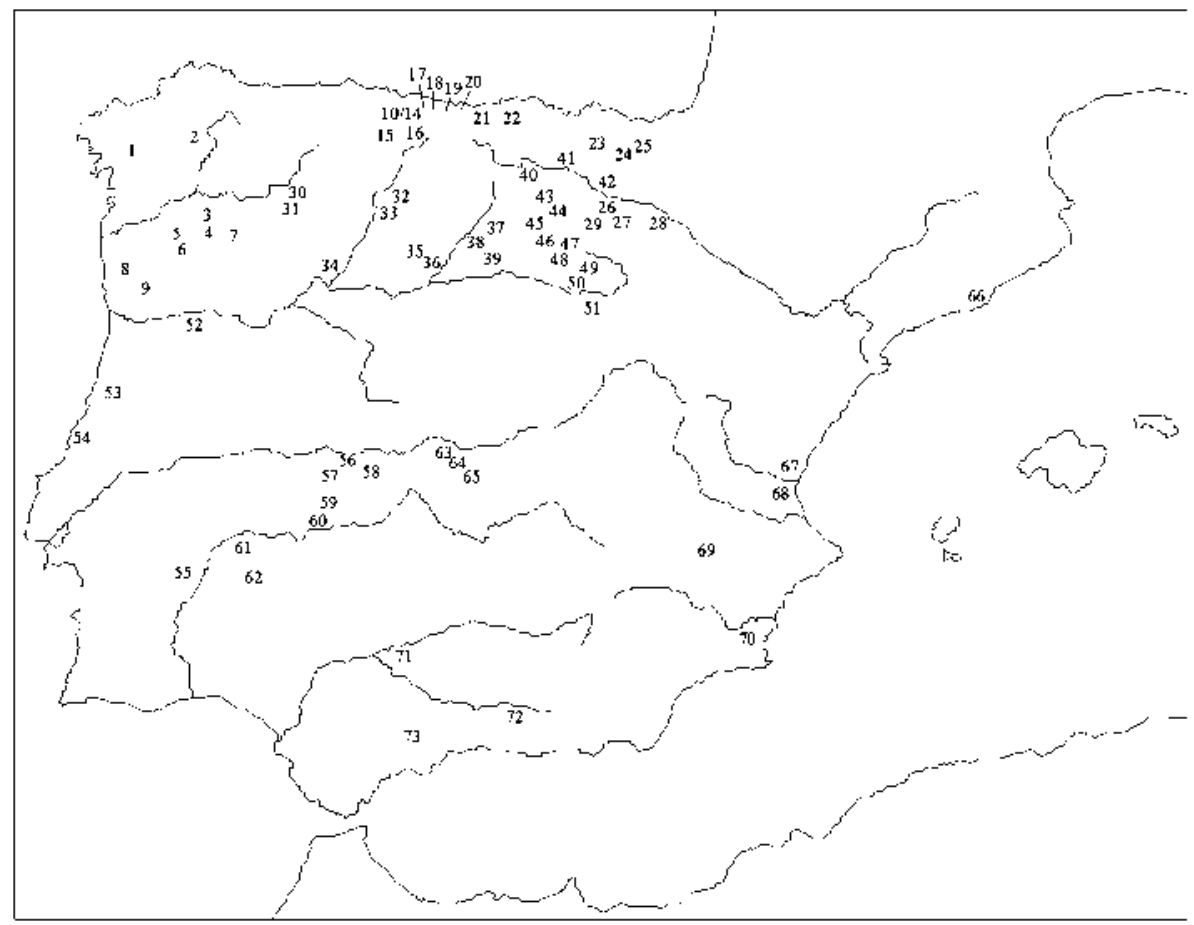

Figura 1. Mapa de España con los lugares citados

1, Santiago de Compostela (La Coruña); 2, Bóveda (Lugo); 3, Sta. Eufemia de Ambía; 4, S. Martiño de Pazó; 5, S. Miguel de Celanova; 6, Sta. Comba de Bande; 7, Sta. María de Mixos; 8, S. Frutuoso de Montelios (Orense); 9, S. Torcato de Guimarães (Braga, Portugal); 10, S. Julián de los Prados o Santullano; 11, Sta. María de Bendones; 12, S. Miguel de Liño; 13, Sta. María del Naranco; 14, La Cámara Santa (Oviedo); 15, S. Adriano de Tuñón; 16, Sta. Cristina de Lena; 17, S. Pedro de Nora; 18, S. Salvador de Valdediós; 19, S. Salvador de Priesca; 20, Santiago de Gobiendes (Asturias); 21, Sta. María de Lebeña; 22, S. Román de Moroso (Santander); 23, S. Román de Tobillas; 24, catedral de Vitoria; 25, Sta. Basilisa de Zalduendo (Álava); 26, Sta. María de los Arcos de Tricio; 27, Sta. Coloma; 28, Ventas Blancas; 29, S. Millán de la Cogolla de Suso (La Rioja); 30 , Sto. Tomás de las Ollas; 31 , Santiago de Peñalba; 32, S. Miguel de Escalada; 33, Marialba (León); 34, S. Pedro de la Nave (Zamora); 35, S. Cebrián de Mazote; 36, Sta. María de Wamba (Valladolid); 37, Vilella; 38, S. Juan Bautista de Baños; 39, Hérmedes de Cerrato (Palencia); 40, Stas. Elena y Céntola de Siero; 41, Sta. María de Mijangos; 42, Buradón; 43, S. Felices de Oca; 44, la Asunción de S. Vicente del Valle; 45, Quintanilla de las Viñas; 46, S. Pedro de Arlanza; 47, Barbadillo del Mercado; 48, Sta. Cecilia de Barriosuso (Burgos); 49, Fuentearmengil; 50, S. Miguel de Gormaz; 51, S. Baudelio de Berlanga (Soria); 52, S. Pedro de Balsemão; 53, S. Pedro de Lourosa; 54, S. Gião de Nazaré; 55, Vera Cruz de Marmelar (Portugal); 56, el Gatillo; 57, Sta. Olalla; 58, la Portera; 59, Sta. Lucía del Trampal (Cáceres); 60, barrio de Moreria, Mérida; 61, Valdecebadar; 62, S. Miguel de los Fresnos (Badajoz); 63, Las Vegas de Pueblanueva; 64, Sta. María de Melque; 65, S. Pedro de la Mata (Toledo); 66, catedral de Barcelona; 67, catedral de Valencia; 68, Pla de Nadal (Valencia); 69, el Tolmo de Minateda (Albacete); 70, La Alberca (Murcia); 71, mezquita de Córdoba; 72, Gabia la Grande (Granada); 73, Bobastro (Málaga).

como indicadores cronológicos absolutos (la decoración o la epigrafía), los cuales se entienden como relativos gracias a la estratigrafía. La reinterpretación de otra fuente de datación tradicional como es el documento escrito y la práctica de análisis físico-químicos (carbono 14, dendrocronología y termoluminiscencia, entre otros) de los materiales constructivos completan la argumentación de la nueva propuesta.

Sin embargo, a pesar de este desarrollo metodológico, debemos tener en cuenta ciertas limitaciones en la valoración del trabajo. Por un lado, nuestros ejemplos se sitúan en el norte, occidente y centro de la Península, dejando fuera amplias regiones, entre las que destacan como más importantes la actual Cataluña (BARRAL 1981), por motivos historiográficos, o el vacío de Andalucía (fig. 1), ésta por causas geográficas e históricas. Por otro, se hace referencia a un sector concreto de la arquitectura, el de carácter eclesiástico. El desconocimiento de la arquitectura doméstica (civil, palacial, militar) impide establecer comparaciones o aproximaciones globales al panorama arquitectónico alto medieval y, en el caso que nos afecta, a las técnicas constructivas. A un caso aislado como el del palacio ovetense de Sta. María del Naranco, Oviedo (Asturias) se añaden nuevos hallazgos que comienzan a cambiar este panorama: asentamientos domésticos documentados por VigIL (2000) y AZKARATE y QUiRós (2001), el complejo de Plá de Nadal (Valencia, JUAN y PASTOR 1989), los edificios monásticos de Sta. María de Melque (Toledo, Caballero y Fernández MIER 1999; Id. 2004b e Id. y Murillo 2005), los palacios de Morería (Mérida, Mateos y Alba 2000 y Alba 2001) y el episcopal de Barcelona (BONNET y BELTRÁN 2001).

Con respecto a la metodología, la estratigrafía sólo ofrece cronologías relativas. Las dataciones aportadas por los análisis arqueométricos o epigráficos y la estratigrafía se complementan y ordenan en una secuencia. En otras ocasiones, las dataciones absolutas ofrecen contradicciones con los modelos de partida (Sta. Comba de Bande, Orense, termoluminiscencia s. VII, CABAllero y otros 2004; S. Pedro de la Nave, Zamora, dendrocronología y carbono 14, ss. VI/VIII, 
AlOnSO y otros 2004 y Caballero 2004c; Sta. María de Melque, Toledo, carbono 14, ss. VII/VIII, CABALLERO y otros 2003). Consecuentemente, la ausencia de indicadores cronológicos directos dificulta establecer series cronotipológicas. La datación tipológica, principalmente en el campo de la decoración, sigue siendo centro de discusión, dada la importancia que tiene para la cronología final en los estudios tradicionales y, por ello, para decidir la discusión entre los dos modelos explicativos. Por lo tanto, se mantiene cierta confusión entre los estudios tipológicos (especialmente el decorativo, pero también los constructivos) y estilísticos. La relevancia otorgada a este planteamiento tradicional (de lo que puede ser un ejemplo esta monografía) suele ser índice de la escasa recepción y comprensión de los análisis arqueológicos (especialmente la estratigrafía y la arqueometría) en la identificación de la cultura material y en el debate actual. Es evidente que, igual que el desarrollo de los estudios cerámicos fue unido a la previa mejora y desarrollo de la excavación estratigráfica, debe potenciarse el estudio sistemático de las distintas tipologías arquitectónicas a la vez que se realizan los análisis estratigráficos, ausencia a la que nosotros no somos ajenos.

Por lo que hace a los límites cronológicos, como ya hemos adelantado, nos centramos en el alto medievo, esto es, desde la frontera temporal marcada por el 711 hasta el siglo XI, momento en el que comienza a tener presencia la cultura románica. Ello no exime de algunas referencias a la arquitectura del periodo tardoantiguo como medio para explicar las novedades que, en nuestra opinión, caracterizan a la cultura arquitectónica del alto medievo, a la que trasladamos, como se sabe, gran parte de la arquitectura que se considera de época visigoda.

El texto, pues, debe entenderse como una aproximación a la identificación de talleres arquitectónicos o grupos de trabajo mediante el estudio de las técnicas constructivas, las cuales entendemos como el resultado de un largo procedimiento que comprende desde la talla en cantera hasta el acabado del edificio. El término de técnica constructiva se emplea frecuentemente como sinónimo de aparejo o fábrica, remitiéndose únicamente a la tipología muraria o arquitectónica, cuando en realidad hace referencia a un ciclo productivo con una serie de actividades organizadas y una finalidad concreta, que comienzan en la cantera y terminan en la ejecución del edificio y que engloban diferentes materiales y oficios no siempre bien diferenciados: el proyecto o el diseño, la elección y tratamiento del material y su transporte, la construcción con la puesta en obra, la talla, la decoración y el acabado; actividades que corresponden al arquitecto, albañil, cantero, carpintero, escultor, estucador, entre otros. Estas variables dan lugar a diferentes tipos de fábricas. En primer lugar, el tipo de material elegido o disponible define la presen- cia y, hasta cierto punto, la propia calidad del edificio. La utilización exclusiva o combinada de sillería de cantera o de expolio y de sillarejo o mampostería y de material latericio da lugar a fábricas simples o mixtas y supone el reflejo del trabajo único o conjunto del cantero y del albañil. Todas las técnicas tienen una etapa de extracción en "cantera», ya sea mampuesto, sillar nuevo o incluso expolio, y otra «a pie de obra", antes y/o después de su puesta en alzado, no necesariamente excluyentes, lo que aboga por un trabajo conjunto de distintos operarios, unos más especializados y otros menos cualificados. Ni siquiera el material reutilizado descarta la presencia de un cantero ya que se exige un mínimo de conocimientos para la extracción, corte y ajuste del expolio.

Las labores de análisis y documentación llevadas a cabo por diferentes equipos, con diversos fines y resultados, han enriquecido notablemente el campo de datos para el estudio de la arquitectura alto medieval, pero éste se encuentra aún en un estado embrionario, con varios proyectos y líneas de investigación en marcha, de los cuales se deben esperar ulteriores conclusiones. Reconocer e interpretar los datos que nos ayudan a identificar las diferentes técnicas constructivas es la labor aquí pretendida, pero como balance provisional, debemos apuntar que estas conclusiones son aún escasas y, a menudo, aisladas, por lo que el establecimiento de relaciones tipológicas y técnicas entre diferentes conjuntos puede ser todavía precipitado. La carencia de análisis monográficos impide conocer la secuencia estratigráfica, histórica y técnica de las edificaciones, por lo que a veces se cae en la mera descripción.

\section{PROYECTO}

El proyecto comprende la organización y ordenación temporal de las fases constructivas. La primera de ellas es la concepción del edificio. Las fuentes escritas en torno a la proyección de las construcciones son, en la práctica, inexistentes, por lo que la fuente es el mismo edificio y el método, el reconocimiento de la medida y de la modulación, es decir, la repetición de las dimensiones y figuras geométricas que determinan la disposición de los elementos arquitectónicos y la forma de la construcción.

La arquitectura prerrománica asturiana ocupa un lugar singular dentro de los análisis de modulación gracias al trabajo desarrollado por ARIAS PÁRAMO (2001, con bibliografía anterior). El estudio sistemático de las iglesias asturianas, comprendidas entre finales del siglo VIII y comienzos del $\mathrm{X}$, reconoce la aplicación de un sistema de modulación estipulado en la ejecución de estas construcciones eclesiásticas. Planta, alzado y elementos arquitectónicos se ven sujetos a una regla modular que determina la disposición espacial y dimensiones de todos ellos y que, actualmente, es una im- 


\begin{tabular}{|c|c|c|c|c|c|c|c|c|c|c|}
\hline & Semis & Septunx & Dodrans & Deunx & Pes & Palmipes & Cubitus & Gradus & Passus & Decempeda \\
\hline S. Julián de los Prados & & & 0,22 & & 0,2957 & 0,37 & & 0,74 & 1,479 & 2,947 \\
\hline S. Pedro de Nora & & & 0,2478 & & 0,309 & & & & & 3.09 \\
\hline S. Adriano de Tuñón & & & 0,248 & & 0,309 & & & & & 3,09 \\
\hline Cámara Santa & & & & & 0,315 & 0,397 & 0,428 & 0,794 & & 3,15 \\
\hline Sta. Comba de Bande & & & & 0,2967 & & & & & & \\
\hline S. Pedro de la Mata & & & & & & 0,4049 & & & & \\
\hline Sta. María de Bendones & & & & & 0,324 & & 0,486 & & & 3,23 \\
\hline S. Pedro de la Nave & 0,1622 & & & & 0,3243 & & 0,4865 & 0,8108 & & 3,24 \\
\hline Sta. Cristina de Lena & & & 0,262 & & 0,326 & 0,4075 & 0,489 & & & 3,25 \\
\hline Santiago de Gobiendes & & & & 0,316 & 0,326 & & 0,489 & & & 3,249 \\
\hline Sta. María del Naranco & & 0,1936 & & & 0,33 & 0,416 & 0,498 & 0,83 & & 3,33 \\
\hline S. Miguel de Liño & & 0,1957 & & & 0,3317 & 0,4151 & 0,4980 & 0,8296 & 1,6603 & 3,3088 \\
\hline S. Salvador de Valdediós & & 0,1947 & & & 0,33 & 0,416 & 0,498 & 0,83 & & 3,32 \\
\hline S. Salvador de Priesca & & & & 0,30 & 0,33 & 0,4158 & 0,498 & 0,831 & & 3,33 \\
\hline Sta. María de Melque & & & & & & & 0,4984 & & & \\
\hline Sta. María de Wamba & & & & & 0,333 & & & & & \\
\hline Sta. Lucía del Trampal & 0,1666 & & & & 0,3333 & & & & 1,67 & \\
\hline S. Pedro de Arlanza & & & & & & & 0,5013 & & & \\
\hline Sta. María de Lebeña & & & & & 0,335 & & & & & \\
\hline S. Juan de Baños & & & & & & & 0,5077 & & & \\
\hline
\end{tabular}

Figura 2. Cuadro de unidades de medida de las iglesias alto medievales (según Caballero y Sáez 1999: 111, Arias 2001: 280 e Id. s/a: 44)

portante herramienta para completar la forma original de los edificios arruinados. También se han efectuado otras propuestas de modulación en Bobastro (Málaga, PUERTAS 1979), Santa María de Melque ${ }^{2}$, Santa Comba de Bande y San Pedro de la Mata (Toledo, Caballero y Latorre 1982), San Pedro de la Nave (Zamora) y San Pedro de Arlanza (Burgos, Caballero y ArCe 1997), San Juan de Baños (Palencia, Caballero y Feijoo 1998) y Santa Lucía del Trampal (Cáceres, CABAllero y Sáez 1999).

Metodológicamente, se debe diferenciar en primer término la unidad de medida (fig. 2). Obviando las irregularidades presentes en todos los edificios, las unidades de medida conocidas responden a dos sistemas distintos, uno que sigue la dimensión del pie romano, de cerca de $30 \mathrm{~cm}$., y otro al drusiano o carolingio, sobre $33 \mathrm{~cm}$., que se impone en época medieval y que corresponde al codo de $50 \mathrm{~cm}$. Ambos aparecen coetáneamente en los edificios asturianos, y queda por decidir si corresponden a sistemas locales hispanos o si, uno o los dos, se reintroducen o se aportan con la nueva cultura omeya y andalusí.

\footnotetext{
${ }^{2}$ Hipótesis criticada por JIMÉNEZ (1982) junto a las propuestas para los edificios de Las Vegas de Pueblanueva (Toledo) y San Baudelio de Berlanga (Soria) de acuerdo, en su opinión, a una proyección teórica errónea y no constatable en el edificio.
}

Por otro lado, hay que plantear el carácter práctico de la modulación. Cómo se efectuaría el paso real desde el proyecto a su aplicación a pie de obra. En otras palabras, si es necesaria la presencia del arquitecto para su ejecución o es fácilmente comprensible por parte de los constructores. Igualmente, qué método e instrumentos se utilizan para su implantación en el terreno (fig. 3).

El estudio de la modulación quizás pueda diferenciar reglas de modulación, con sus grupos de edificios, y la secuencia de las escuelas que las utilizaron. Sin embargo, por hoy puede decirse que los trazados observados en otros edificios se asimilan básicamente a las reglas señaladas para la arquitectura asturiana.

\section{ELECCIÓN, EXTRACCIÓNY PRODUCCIÓN DE MATERIAL}

Las condiciones que influyen en la elección, extracción y producción o transformación del material son múltiples y variadas: disponibilidad y distancia de la fuente de material, vías de comunicación y transporte y caracteres de explotación y producción.

\section{Madera}

Aunque apenas conservamos restos de la madera empleada en la arquitectura alto medieval de piedra, podemos afirmar que se empleó para distintas funciones, como piezas 

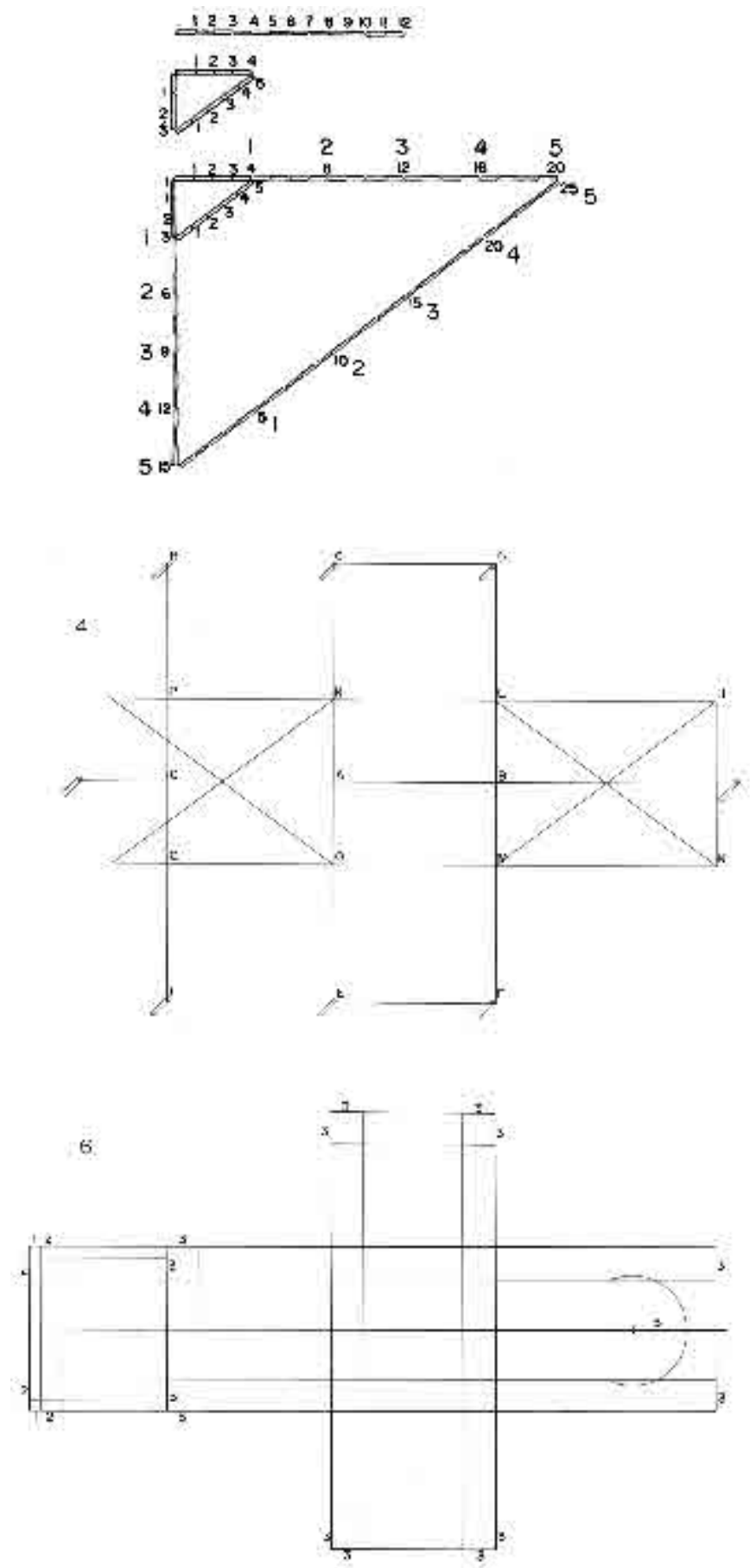
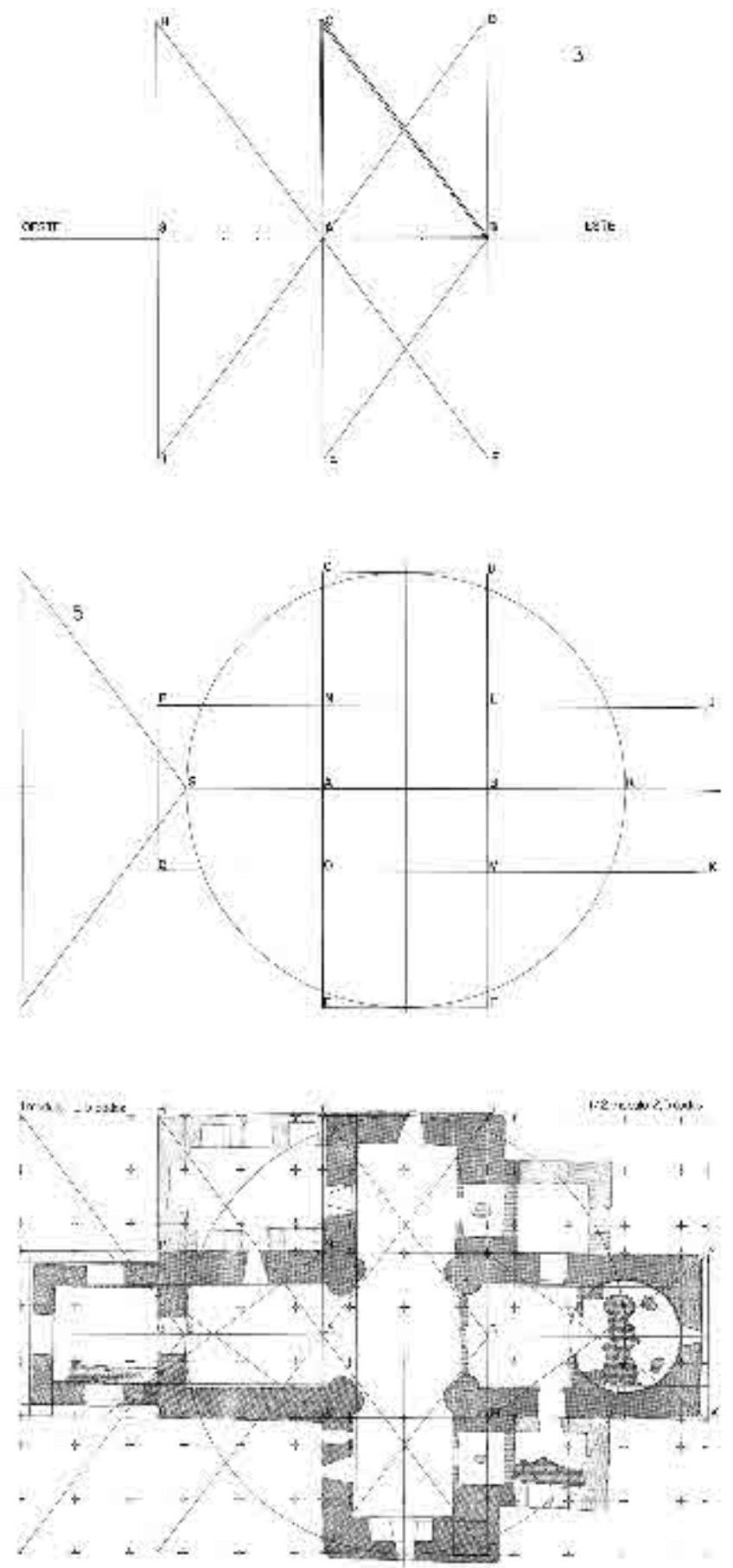

Figura 3. Propuesta del trazado de Melque con una cuerda de 60 codos de largo utilizada con el triángulo pitagórico (según Caballero y Cámara 1989)

portantes, de atado, cubierta, mobiliario y auxiliar de la construcción (andamios y cimbras).

Vigas de madera empleadas como cargaderos de vanos adintelados conocemos en la puerta principal oeste de Baños, en Sta. Cecilia de Barriosuso (Burgos), S. Miguel de Gormaz y Fuentearmengil (Soria), S. Miguel de Escalada y Santiago de Peñalba (León). En ocasiones, estas vigas alternaron o se descargaron con arcos, como ocurriría con las desaparecidas de los arcos peraltados de la Nave o con las de los de herradura de Gormaz, Fuentearmengil y Berlanga (Soria; Caballero y ARCE 1997).

De difícil constatación, a no ser por un desmonte murario o una ruina del conjunto, las piezas de atado en madera se emplean como elementos de refuerzo en la consecución de estabilidad y cohesión de las fábricas de sillería (CABALLERO y ARCE 1997). Ejemplo único por el momento es el de la igle- 
sia de San Pedro de la Nave, donde grapas de madera en forma de cola de milano unen longitudinalmente los sillares para evitar la separación de las hojas del muro por pandeo. Las cajas de las grapas también son visibles en la viga que ataba sus muros laterales por encima del arco del triunfo. Otro empleo es el de zunchos de madera introducidos en cajeados tallados en la sillería, como en los muros de una hoja del aula de la Asunción de San Vicente del Valle/2 (Burgos, Aparicio y FuENTE 1996). Más dudoso es su uso, con parecida función, en el ábside de Santa María de Arcos de Tricio (La Rioja), en la parte alta exterior del testero occidental de Baños, en el crucero de Wamba (GÓmez Moreno 1919) y en Sta. María de Bendones (Asturias; CABAllero y ArCe 1997). Otros elementos de atado son los estribos de apoyo de las bovedillas de la tribuna de Berlanga y los zunchos de la capillita adosada al pilar como una torrecilla. Un sistema análogo a éstos se conoce en el alminar de la mezquita de Córdoba de época de 'Abd al-Rahm,n III (HERNÁNDEZ 1975) con vigas en las cajas de los sillares. En el mismo edificio, las intervenciones efectuadas en las cúpulas de la maqsura y la capilla de Villaviciosa descubren un sistema de atado y apoyo de éstas compuesto por un entramado de viguería (MARFIL 1998).

Las cubiertas de época original no se conservan. Las principales candidatas serían las de las iglesias asturianas de planta basilical, pero sus estudios son escasos y revelan fechas muy tardías, como las de Santullano y San Adriano de Tunón (Asturias), restauradas en el siglo XII (ARIAS y ADÁN 1991). Algo semejante ocurre en la mezquita de Córdoba, cuyas cubiertas se restauran en el s. XIII según TORRES BALBÁs (1936, originales del X según HeRNÁNDEZ 1928). En Baños se conserva aún el arranque de una viga de su cubierta original correspondiente al tirante más occidental de su nave meridional.

Es evidente que los andamiajes y cimbras eran necesarios en todos los casos, ya fueran independientes o empotrados. De mechinales para andamios se conservan ejemplos tanto en sillería como mampostería. Los casos del Trampal, en que andamios y cimbras debían formar un sistema homogéneo, y Berlanga, donde se han conservado las maderas de los puentes o agujas, son los más llamativos.

Elementos singulares, mobiliario litúrgico, escaleras o suelos de tribunas, se conocen a veces por sus restos: modillón tallado y vigas en el iconostasis de Escalada (Gómez Moreno 1919) y pasamanos en la tribuna de Berlanga; sus interfaces, huecos para trabes de cortinas en una gran mayoría de iglesias (la Nave, Baños, Melque); o sus apoyos, ménsulas en las tribunas de São Gião de Nazaré (Portugal). De las puertas de madera solo quedan las huellas de quicios y cierres.

Las piezas lígneas se revalorizan ahora como indicadores cronológicos gracias a la aplicación de análisis de carbono 14 y dendrocronológicos. Los análisis comienzan a apor- tar resultados, aunque habrá que esperar a otros estudios en curso para poder obtener conclusiones generales, no solamente de índole cronológica (fechas relativas y absolutas), sino también sobre el origen del material (piezas originales o reutilizadas) o la zona geográfica de procedencia (entorno inmediato o lejano). Dataciones aceptadas como la de Berlanga a comienzos del siglo XI (ZOZAYA 1976) se retrasan en medio siglo por el análisis de los puentes de los andamios y las vigas de atado (AlONSO y otros 1997 y Rodríguez Trobajo 2000). El análisis de la viga de la Nave parece confirmar su reutilización de acuerdo a la obtención de una datación post quem entre el 488 y el 594 para su labra (AlONSO y otros $2004^{3}$ ). Las grapas de unión de los sillares se datan en un amplio intervalo comprendido entre mediados del siglo VI y finales del IX (Eid. 2004). El análisis de los cargaderos y la viga de Baños, aun en curso, señala características y curvas dendrocronológicas similares con la viga de La Nave y, por tanto, procedencia y cronología parecidas que, de dejarse arrastrar por la fecha del s. VII de una de las grapa de La Nave, haría ambos conjuntos de este siglo, planteando de este modo dos cuestiones. Por un lado, si ambas iglesias deben considerarse por estos análisis del s. VII o si se reutilizaron en ellas maderas cortadas en este momento, $y$, por otro, la posible existencia de un lugar de abastecimiento común (de origen o de reutilización) para edificios alejados en el espacio. Todos estos ejemplos forman parte de un proyecto de investigación de las maderas de edificios alto medievales (dendrocronología, carbono-14 y arqueología) en los que se han efectuado previamente análisis estratigráficos. Análisis de carbono 14 se están aplicando también en yacimientos en excavación como el conjunto episcopal de Valencia (RIBERA y Roselló 2000), Barcelona (BONNET y BELTRÁN 2001), Sta. María de Mijangos (Burgos, LeCANDA 1999), la catedral de Vitoria (AZKARATE 2001) o Melque (CABALLERO y FERNÁNDEZ Mier 1999 y Id. y otros 2003).

\section{Piedra}

La geografía de los monumentos confirma la importancia de los materiales de origen local en conjuntos de cronología muy diversa. Así por ejemplo, grosso modo, el granito caracteriza los monumentos gallegos y portugueses (Sta. Eulalia de Bóveda, Lugo; Bande, S. Miguel de Celanova, Sta. María de Mixos, Sta. Eufemia de Ambía, S. Martiño de Pazó, Orense; S. Fructuoso de Montelios, S. Pedro de Lourosa, Portugal) y las iglesias de la zona lusitana y toledana, junto con la

\footnotetext{
3 Esta fecha retrasa la obtenida en los primeros análisis (RODRÍGUEZ TROBAjO y otros 1998), la cual se movía en una horquilla que abarcaba desde el 330 al 474. Caballero (2004c) recoge y discute las dataciones de estas maderas en sus conclusiones sobre el edificio.
} 
pizarra (Melque y la Mata; reutilizado en el Trampal; S. Miguel de los Fresnos y Valdecebadar, Badajoz; y la Portera y Santa Olalla, Cáceres); los ejemplos leoneses, la pizarra (Marialba, Santiago de Peñalba, Sto. Tomás de las Ollas, León) y la caliza (Escalada; S. Cebrián de Mazote, Valladolid); las edificaciones de la cuenca del Duero y el alto Ebro, la caliza y la toba calcárea (Quintanilla de las Viñas, Arlanza; la Asunción; Sta. Elena y Céntola de Siero, Barbadillo del Mercado y Sta. Cecilia de Barriosuso, Burgos; S. Román de Tobillas, Álava; y el resto del grupo burgalés y riojano, S. Millán de la Cogolla de Suso, La Rioja; Sta. María de Lebeña, Santander; Wamba, Valladolid; Villella, Hérmedes de Cerrato, Palencia; Berlanga, Soria, entre otras) junto a la arenisca (S. Felices de Oca reutilizada; Tobillas/1 reutilizada y 2; S. Julián y Sta. Basilisa de Zalduendo y Buradón, Álava; Arlanza, la Nave o Quintanilla). En ocasiones se utilizan varios materiales como ocurre en la Nave, donde se utilizaron grandes lajas de pizarra local para los cimientos y se aportó de fuera sillería de arenisca y granito, utilizada esta última en el arranque de las esquinas y de la habitación descubierta a sus pies.

El notable desconocimiento de la ubicación y explotación de las canteras en época alto medieval no permite aportar datos al análisis de esta fase del proceso constructivo, afirmación que se puede generalizar para el contexto mediterráneo (Ward-Perkins 1971, como referencia clásica). Nuestros datos se limitan a anotaciones aisladas en la procedencia de la sillería arenisca de la Nave (GOMEZ Moreno 1927 y CoRzo 1986, propuestas contrarias), Quintanilla (ANDrÉs y ABÁSOlo 1980), Mijangos (LECANDA 1999, signos de cantera antigua) o San Vicente de Valencia y Pla de Nadal, ambas construcciones alimentadas por una cantera común (ROSELló y SORIANO 1998). El conjunto asturiano ha sido objeto de distintos estudios que confirman el mismo fenómeno de proximidad de las canteras, como ejemplifican, entre otras, Liño y el Naranco (EsBERT y otros 1992).

Por otro lado, el fenómeno de la reutilización del material constructivo y decorativo es común y extendido en este periodo. Ejemplos significativos constituyen la sillería de Bande, Quintanilla, la Portera o los Fresnos. Otros casos, como los de la Asunción y Arlanza, según confirma la lectura arqueológica de sus alzados, reutilizan una y otra vez el mismo material de la iglesia de época anterior, por lo que el módulo de los sillares se reduce por el retalle de la piedra. Las grandes columnas de origen romano de la arquería del aula de Tricio/2, junto a los capiteles y otros elementos epigráficos (como en Arlanza) incluidos en los muros, muestran el expolio a gran escala de uno o varios edificios significativos (Sáenz 1999, con bibliografía anterior). Pero no es fácil distinguir si la sillería de un edificio es reutilizada o sacada de cantera. Por una parte, el retalle de los paramentos, una vez colocados los sillares, borra las huellas del uso previo $y$, por otra, el retalle no significa obligadamente que los sillares se hallan reutilizado pues han podido llegar «almohadillados» de la cantera, como confirma Suso/2 (CABALLERO 2004d). Sólo en algunos casos la reutilización es evidente como en Arlanza (caras internas del ábside sin retallar indicando la procedencia reutilizada), Quintanilla y Baños (conservación de huecos de su primer uso) o Bande (módulo y forma de los sillares de granito). También son frecuentes las fábricas de mampostería o sillarejo de cantera combinadas con sillares de encadenado de procedencia romana: Valdecebadar, Mijangos, el Trampal, Nazaré, Buradón, el Tolmo de Minateda (Albacete) o Valencia. La sillería de granito de Melque, Montelios (Portugal), Celanova y otros ejemplos gallegos procede de cantera. Se da por supuesto que la mampostería o sillarejo procede siempre del terreno circundante y caracteriza los tipos asturianos, además de iglesias como el Trampal o Nazaré, entre otras.

Si nos adentramos en el campo decorativo, la reutilización es mucho más común de lo que se pensaba. Aunque la propuesta de que los conjuntos mozárabes reutilizaban capiteles del siglo VI (Domínguez 1992) no esté aceptada, la revisión de éstos y otros ejemplos como los de Baños (CABALlero y Feijoo 1998), la Nave, Quintanilla, Bande, el Trampal, Melque, la Asunción/3 y 4, Nazaré y Marmelar (CABALlero y ARCE 2004) o las decoraciones de Santullano (NOACK 1995), Liño y Lena (Asturias, Noack 1986 y 1992) señalan la necesidad de renovar el análisis arqueológico de la decoración. El análisis estratigráfico permite descubrir los distintos sistemas decorativos (o «talleres») utilizados a lo largo de la vida de un edificio, las características de los grupos (o «maestros») que compuso cada sistema e importantes indicios sobre los modos de producción de los talleres. La contextualización de estos grupos y sistemas decorativos permite su adecuada valoración como indicadores cronológicos y como referente económico y simbólico de las sociedades que los crearon y a las que sirvieron.

A título de ejemplo es significativo el caso de Baños, cuyo sistema se ha descubierto compuesto por cuatro grupos (dos reutilizados, uno retallado y otro tallado ex profeso) lo que ha relativizado el supuesto carácter absoluto de su inscripción regia, abriendo una nueva explicación sobre su significado. En la Nave (uno de cuyos maestros recompuso su grupo decorativo reutilizando y sacrificando sus propios materiales) y Quintanilla, los talleres decorativos están estrechamente relacionados con los constructivos; mientras que uno de los de Bande y el del Trampal prefabrican las piezas al margen del taller constructivo al que sirven.

Junto al horizonte simbólico de la reutilización (VvAA 1999, con bibliografía), este fenómeno plantea, efectiva- 
mente, cuestiones interesantes en lo que atañe a la producción y a la técnica constructiva. Como ya hemos visto en otros casos, se confirma la convivencia de dos sistemas de obtención del material, por la explotación de canteras y por el expolio de edificios antiguos. La presencia del cantero es necesaria en ambos casos. ¿Se perdieron los talleres de cantería y la explotación de las canteras, perviviendo en una etapa intermedia el aprovechamiento del expolio que necesitaba una menor especialización?, ¿qué ventajas reales ofrece la reutilización de material procedente de otras edificaciones?, ¿hay una diferencia de esfuerzo suficientemente rentable entre el trabajo de explotación de una cantera y la labor de desmonte de un edificio? Los factores de disponibilidad (situación política, geografía, transporte y vías) y características constructivas del material deben ser fundamentales en la elección del material, pero tal vez deban considerarse otras premisas que por el momento escapan del análisis arqueológico. La propiedad, regímenes de explotación y rentabilidad de las canteras, la organización del trabajo o la especialización deben haber determinado el empleo de material constructivo, pero ¿cómo saberlo?

\section{Cerámica}

Como en el caso de las canteras, existe un gran desconocimiento en lo que a producción de cerámica constructiva en época alto medieval se refiere. El cese de la producción de ladrillo y teja en todo el marco mediterráneo parece un hecho constatado para época bajo imperial y alto medieval, teniendo que esperar a la época pleno medieval para la recuperación de la producción de cerámica constructiva (QUIRÓs 1998). En la Península Ibérica, la reutilización de ladrillo justificaría esta «normalidad». Sin embargo, el fenómeno caracterizador de la reutilización ha llevado a dar por sentado muchos datos que ahora se intentan revisar con la aplicación de análisis de datación (termoluminiscencia, cronotipología). El análisis por termoluminiscencia de los ladrillos de las bóvedas de Bande lleva a rechazar su origen romano y ofrece unas fechas de mediados del siglo VII (CABALLERO y otros 2004). Las tejas del monasterio de Melque se fechan en la segunda mitad del s. VIII (CABALLERO y FernÁndeZ Mier 1999). Por otro lado, las dimensiones obtenidas en ladrillos de los ejemplos asturianos sugieren una producción en época alto medieval (FERNÁNDEZ MIER y QUiRÓs 2001) sumándose a los ejemplos anteriores. Es evidente la necesidad de un proyecto de investigación de termoluminiscencia de material cerámico, especialmente el asturiano y el mozárabe, que busque no sólo fechas, también su adecuada contextualización y calibración.

El material latericio se emplea preferentemente en arcos y estructuras de abovedamiento. Su disposición dificulta conocer sus dimensiones completas, por lo que es difícil confirmar si continúan la modulación romana o no. Lo encontramos formando las aristas (las Ollas), los arcos (Bóveda, dimensiones por Chamoso 1952) o como material único en las bóvedas de edificios asturianos (Santullano, Cámara Santa, Bendones, Valdediós, aquí combinado con toba, etc., y en los arcos de sus ventanas) y en las bóvedas de Montelios, Bande, Mixos, Celanova, Peñalba), listado del que caen las bóvedas de Escalada y Mazote que, aunque ejecutadas en ladrillo, son obras de restauración (Utrero 2004). El elenco en muros se reduce a las verdugadas de la mampostería del Trampal y los paramentos superiores de la nave central de Escalada, éstos de cronología dudosa.

En época tardo romana, el empleo del ladrillo es similar. Su menor peso, en comparación con la piedra, justifica su uso en elementos estructurales. Lo encontramos en la bóveda de Centcelles (Tarragona, Schlunk y Hauschild 1962) y en las criptas de los mausoleos de Pueblanueva (Toledo, Hauschild 1969), La Alberca (Murcia, Mergelina 1947) y en las bóvedas de los ábsides de las iglesias del Gatillo (Cáceres, Caballero y otros 1991, segunda fase) y el Tolmo de Minateda (Albacete), donde aparece también en la arquería de división del aula (Abad y otros 2000 y Cánovas 2002)

La documentación arqueológica de las tejas es más rara. Material normalmente obviado en los procesos de excavación y restauración (por ejemplo, conservadas hasta 1980 en Valdediós, Arias 1993), se conocen por estratigrafía en escasos ejemplos, como en los edificios monásticos de Melque y la iglesia del Tolmo y las tégulas e ímbrices reutilizadas del Trampal.

\section{PUESTA EN OBRA}

La puesta en obra de los materiales comporta un traslado al lugar y un levantamiento en alzado (andamiaje y cimbras). Del transporte desde cantera al lugar de obra no poseemos dato alguno.

La ausencia de huellas de andamios, no conlleva su carencia. La construcción de edificios de gran altura, como San Millán de Suso, no pueden concebirse sin un medio auxiliar, pero en realidad todos estos edificios, sin excepción, necesitaron de andamios. Los andamios sin puentes o independientes, aprovechando los muros o espacios menores para su apoyo, deben haber sido un modo común, pero hemos de considerar la existencia coetánea de aparejos construidos con

\footnotetext{
${ }^{4}$ Dejamos fuera de este grupo el alzado conservado en la conocida basílica de Carranque (Toledo, Fernández Galiano y otros 2001), así como la iglesia de Los Santiagos de Alburquerque (Badajoz; Alba y Feijoo 2003). Ambas han de ser de una fecha mucho más tardía a la sostenida tradicionalmente: con bastante probabilidad la primera, cuya cronología tardo romana nos parece muy dudosa (Utrero 2004) y de acuerdo con su reciente estudio la segunda, que datamos en plena Edad Media.
} 
otros andamios empotrados en los muros, bien apoyados también en el suelo con almas o colgados o de báscula. Justamente es esta aparente coetaneidad lo que más llama la atención principalmente en los edificios construidos con sillería. Quizás cuando este tema se estudie en profundidad podrá conseguirse una ley cronológica o de taller sobre su empleo.

Conocemos el uso de mechinales para los puentes de andamios empotrados en los edificios de mampostería o de sillarejo. En el Trampal (CABALlero y SÁEZ 1999) se puede estudiar con detalle la relación entre los bancos y los mechinales de los andamios que, a su vez, estarían en relación con el cimbrado de las bóvedas que, a nuestro parecer, cubrían todo el edificio. Probablemente todos los edificios de sillarejo asturiano poseen mechinales para andamios, como la Cámara Santa, Santullano, Naranco, Liño y Nora. Lo mismo debe ocurrir con los llamados mozárabes, como Berlanga (RodrígueZ Trobajo 2000), que conserva las maderas de los puentes de los andamiajes en los mechinales situados a intervalos verticales de 2 m., y Peñalba. Es distinto el caso de los edificios de sillería donde alternan los andamios empotrados (mechinales) y los independientes (ausencia de mechinales). Se observan mechinales recortados en los sillares de los testeros de los ábsides, como en Valdediós y Barriosuso, edificios cuyo aparejo, por ello, se pueden comparar. Entre los independientes destacan especialmente los edificios de perfecta sillería ajustada, tanto de cantera, como es el caso de Melque, como reutilizada, como lo son Quintanilla y la Nave, al menos en parte. Además están en este grupo las portuguesas Montelios, Guimarães y Lourosa. El gran edificio de Suso/2, también sin mechinales, nos orienta sobre la forma de usar estos andamios, que se apoyarían en la sillería «almohadillada» o irregular, tal como fue sacada de cantera y antes de recortar perfectamente su superficie. Emplean mechinales otros edificios de sillería grande más o menos regular, como Baños, Barbadillo, Arlanza/1a, Oca, la Asunción/1 (en las esquinas inferiores), 12 (de forma irregular en los sillares) y /3 (en menor número), Tricio/1; Sta. Coloma, Logroño; Tobillas/1 y /2; S. Román de Moroso, Santander; y el pequeño testero occidental del pórtico de Escalada/2. Observemos, por ejemplo, la ausencia de mechinales en Quintanilla y, al contrario, su presencia en Arlanza/1 y los demás edificios burgaleses y riojanos que podrían estar en relación; o la ausencia en Quintanilla y la Nave y su existencia en Baños. También presenta mechinales la obra de ladrillo de Escalada.

La pretendida funcionalidad constructiva del arco de herradura (CoRzo 1978) no parece responder a tal efecto, dado que su cimbrado no impediría el desarrollo de la construcción. Se emplearían cimbras sin apoyo central, fáciles de montar y reutilizables tanto en los arcos de herradura como de medio punto. Otra vía para economizar cimbras sin debi- litar el edificio se encuentra en la propia técnica: a menudo hallamos arcos donde el salmer y las primeras dovelas tienen un despiece horizontal, el arco (el Trampal) o la bóveda (Melque o la Portera), aunque de apariencia peraltada o de herradura, son rebajados, reducidos exclusivamente a la zona más alta, es decir, a un tercio de su desarrollo.

En el caso de las bóvedas, los mechinales sólo se conocen en el arranque de la fábrica de ladrillos en hiladas horizontales de Bande, por lo que se debe pensar que las impostas efectuarían el trabajo de soportar las cimbras. Pero el uso de cimbras en las bóvedas se puede rastrear además por las huellas o improntas visibles en los intradoses de algunas roscas. Estos son los casos de la bóveda de Santa Eulalia de Bóveda (GÓMEZ Moreno 1949), de la del piso inferior de Santa María del Naranco (UTRERO 2004) o de los husos de la bóveda de las Ollas (GÓMEZ MORENO 1951), todas ellas conservan las improntas de los tablones de las cimbras. En Cataluña, al ejemplo de Boada mencionado por Gómez Moreno (1919), podemos sumar Marquet, Cabrils u Olèrdola, entre otras (UTRERO 2004), cuyas bóvedas presentan las marcas de las cañas que ayudaron a las cimbras de madera en su construcción.

En el proceso de construcción de los muros y cubiertas, se incluye la elaboración de los componentes de cohesión (argamasas) que comporta otro tipo de actividades. En Melque se han hallado, abiertas en el suelo, las piletas de decantación y manipulación de la cal, niveles de talla de los sillares a pie de obra y los agujeros para posibles grúas y para andamios (CASTILlo 1975 cita un horno de cal en Suso, pero desconocemos su cronología). Aunque no tenemos más referencias directas, dada la ausencia además de documentación complementaria gráfica o escrita, como por ejemplo se tiene en época romana o bajo medieval, debemos pensar en una continuidad tecnológica desde época antigua.

\section{APAREJOYTALLA}

\section{El aparejo}

En nuestra alta Edad Media, dejando de lado el problema de su cronología de arranque, inmediata a antes o después del 700, se pueden distinguir dos grandes grupos, el de mampostería con sillería encadenada en esquinas y marcos y el de sillería (fig. 4).

\footnotetext{
${ }^{5}$ Las piezas salientes de los tímpanos del ábside de Quintanilla podrían tener función similar, aunque en las cúpulas sobre pechinas con anillo saliente, no serían necesarias, porque éste cumpliría la función de la imposta o de los apoyos. El hecho de que estas piezas corten los tímpanos de los muros, interrumpan el desarrollo del anillo de la cúpula y que se conserven únicamente en Quintanilla y no aparezcan de la misma manera en ninguna de las demás iglesias riojano burgalesas con ábsides abovedados nos parecen argumentos adicionales para proponer su posterioridad (UTRERO 2004).
} 


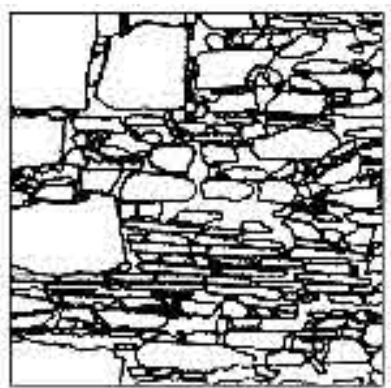

IRAMPAL A

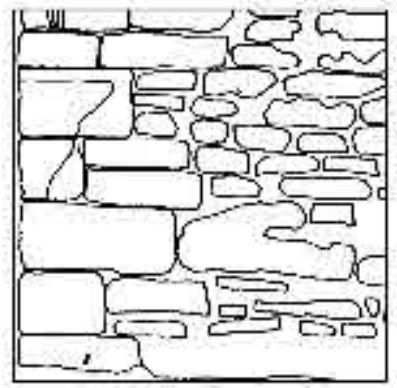

ASUNCION 4

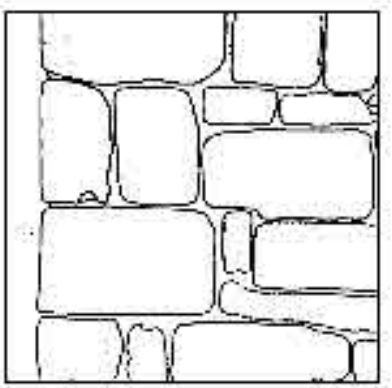

BANDE

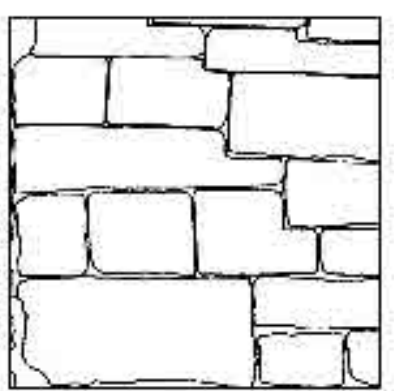

BAÑOS

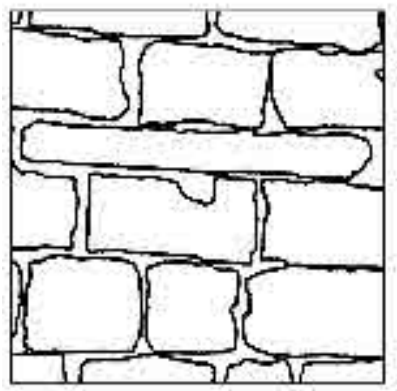

ARLANZA

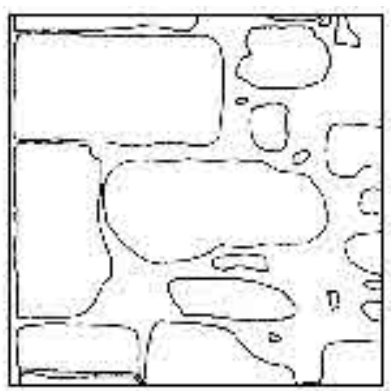

FSC ALADA 1 A

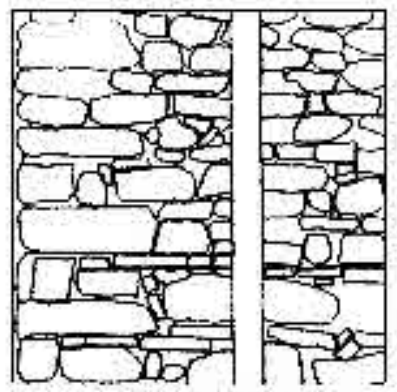

NAZARI

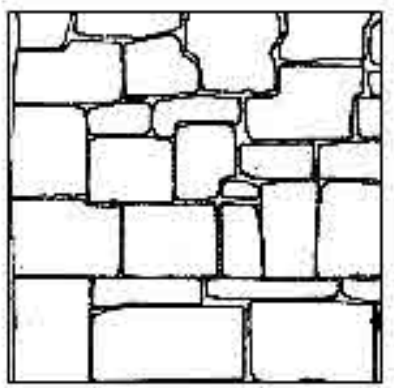

TOBILLAS 1

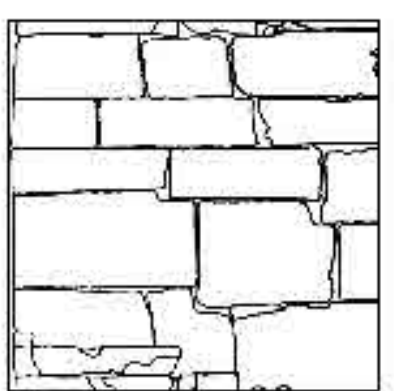

Suso 2

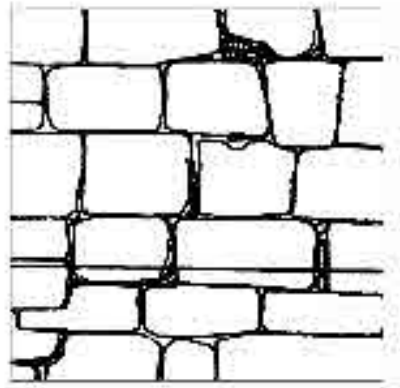

MFLQUF 2

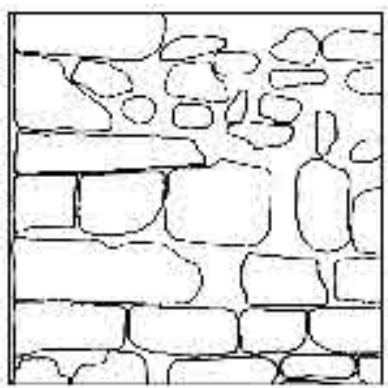

BARRIOSUSO

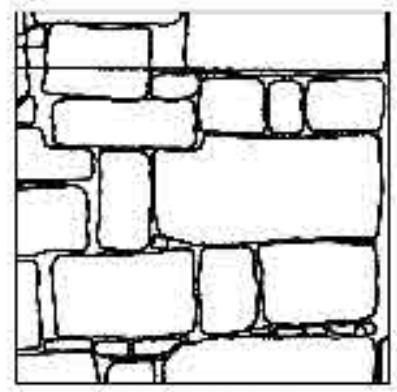

TRAMPAL B

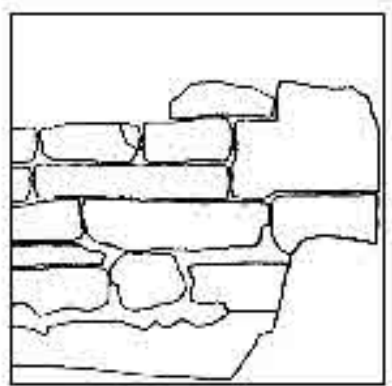

VTAS. BLANCAS

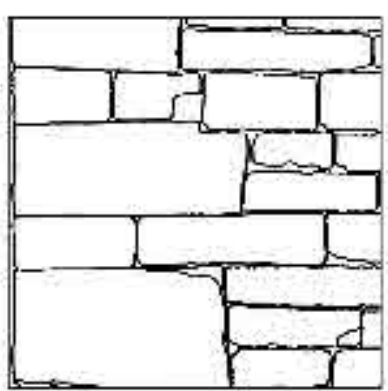

MOROSO

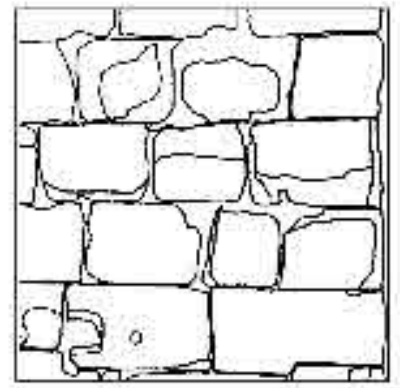

STA. COLOMA

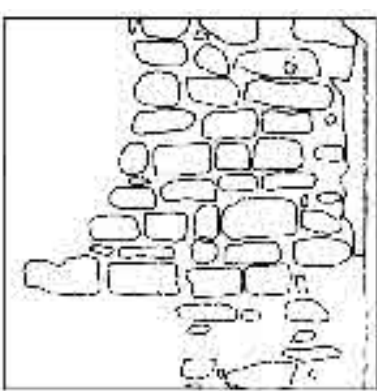

TRKIO 2

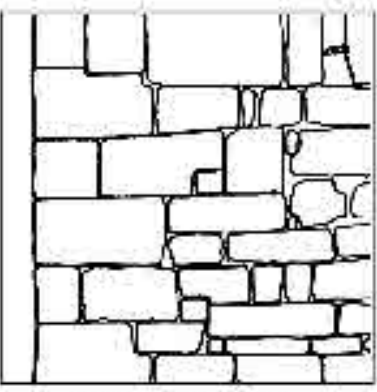

VALDLDIOS 1

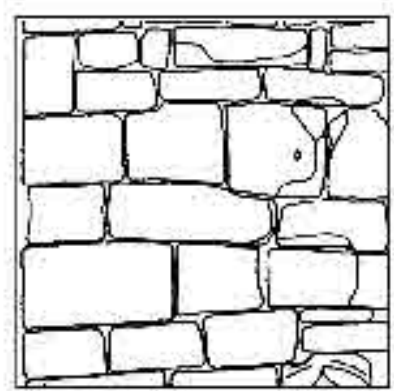

$\mathrm{OCA}$

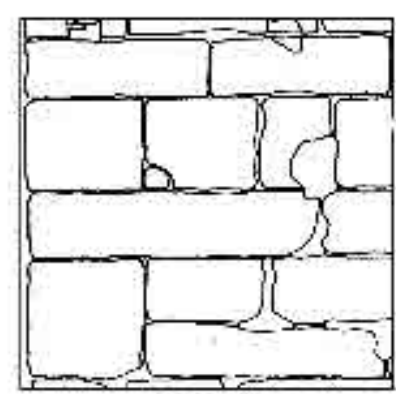

TRICIO I

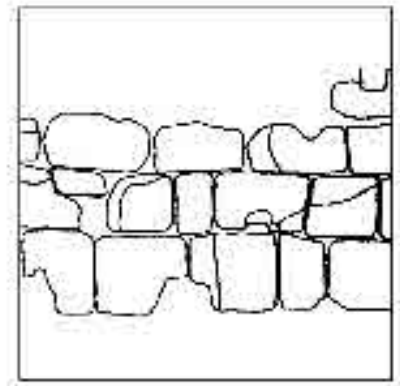

ASUNCTON 3 


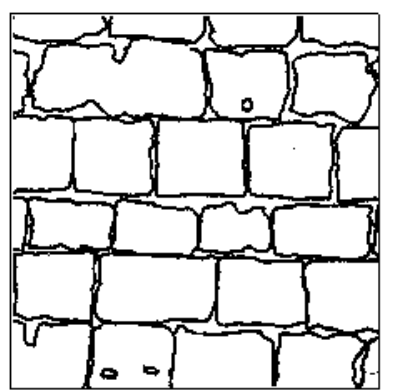

ARLANZA 2

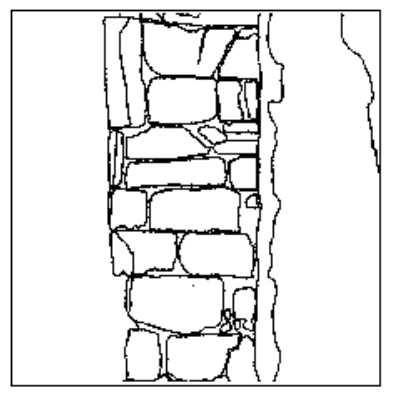

SUSO 1

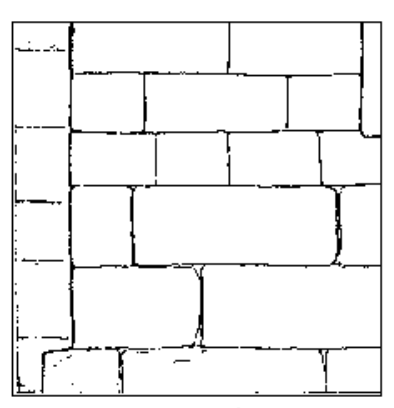

VALDFDIÓS 2

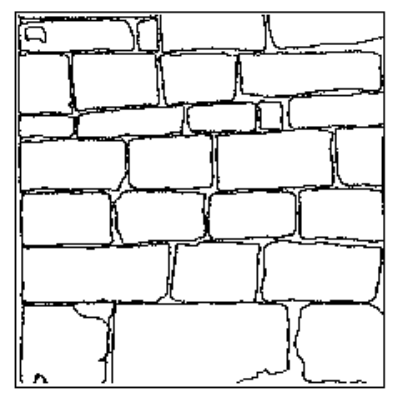

SUSO 3

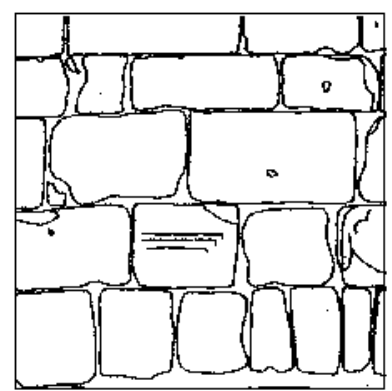

ASUNCION 1

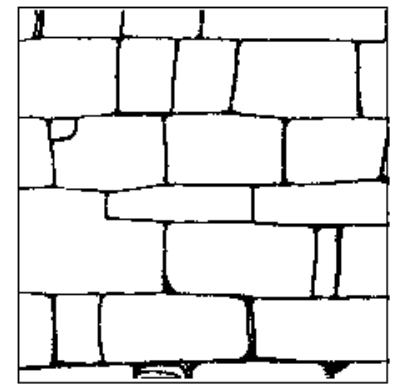

MELQLE I

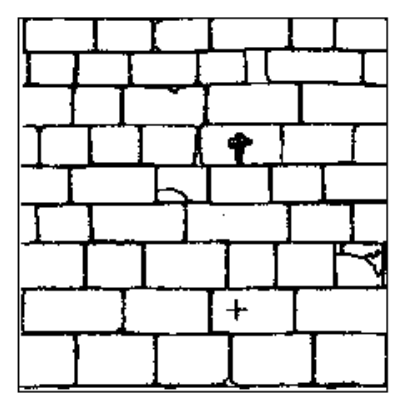

TOBILLAS

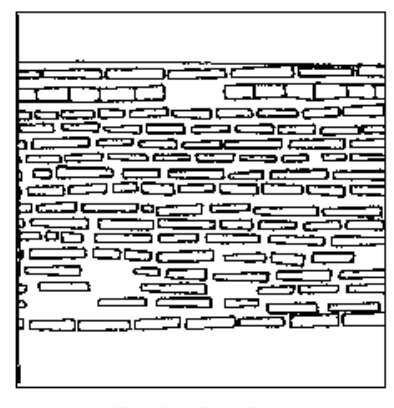

ESCALADA $1 \mathrm{C}$

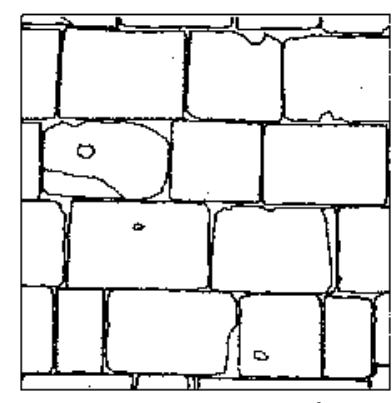

ASUNCION 2

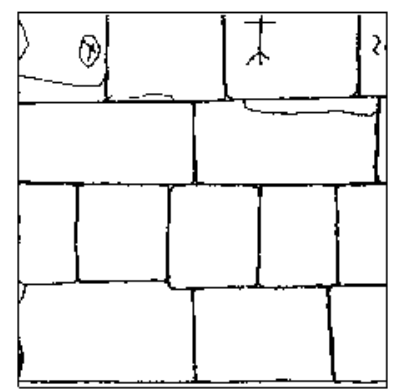

LA NAVE

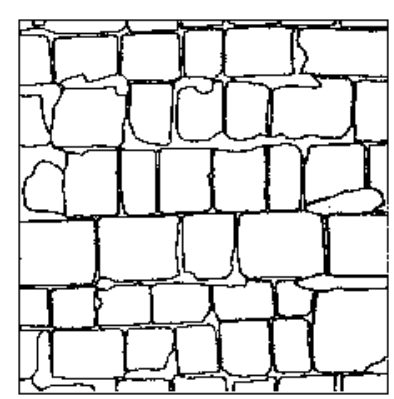

FSCALADA $1 B$

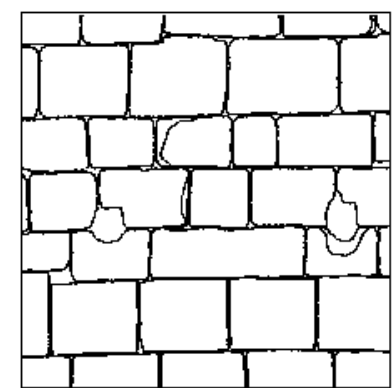

BARBADILLO

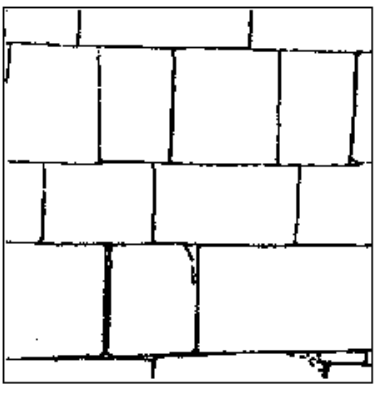

QUINTAN]LLA

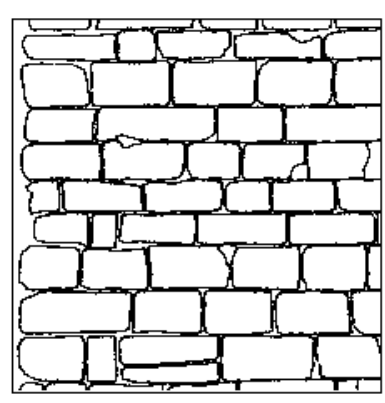

FSCALADA 2

Escala: $1 / 50$
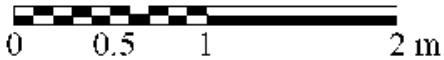
La mampostería o el sillarejo, más regularizado, reforzados con sillería encadenada en esquinas y marcos, es característico del grupo asturiano con apenas excepciones. Dentro de este grupo se observan diferencias, entre los mampuestos más regulares y planos (Santullano, Naranco y Liño) y los más irregulares y grandes (Valdediós y Lena). Propio de este aparejo, tanto en lo asturiano como fuera de él, es que, mientras que las naves se cubren de paños de mampostería, en los testeros la sillería se extiende llegando a cubrir sus estrechos paramentos, como ocurre en el Trampal, Valdediós y Barriosuso, por señalar tres ejemplos separados en el espacio y pertenecientes sin duda a talleres distintos. También son norma los bancos de puesta en obra y los mechinales para andamios. El carácter excepcional de la mampostería del Trampal viene señalada por la presencia de verdugadas de ladrillo. Normalmente la sillería de los encadenados de la mampostería suele proceder de expolio o no estar tallada con la calidad que suele presentar el aparejo de sillería del momento. Otros ejemplos son Escalada/1, Tricio/2, la Asunción/4, Berlanga y Nazaré.

La sillería presenta, dentro de una apariencia también básicamente similar, varios grupos claramente distinguibles por el tamaño y la regularidad de la forma de los sillares y su puesta en obra. El grupo más irregular es el relacionado con los refuerzos de la mampostería ya citados (el Trampal, Valdediós, Barriosuso). A él se pueden añadir Tobillas/1 y Oca, en el que son corrientes el material de expolio y la presencia de mechinales de andamio. La excepcionalidad del Trampal es evidente por la existencia de abundantes cuñas inexistentes en los demás edificios. Un grupo intermedio presenta sillares de mayor tamaño en las esquinas y el resto de la sillería de tamaño grande o mediano aún sin conseguir lechos horizontales e hiladas continuas, en el que es característico por tanto, el desdoblamiento de hiladas y los codos profundos (Arlanza/1; Moroso; Baños; Sta. María de Ventas Blancas, La Rioja). Tricio/1 presenta sillares similares en su tamaño y forma a los anteriores pero con hiladas ya horizontales. Un tercer grupo reduce el tamaño de los sillares que presentan una tendencia a un módulo más cuadrado y regular (Sta. Coloma, Arlanza/2, la Asunción/1, Barbadillo). En este grupo podría incluirse también la sillería que hemos denominado «ajustada» por la calidad con que se unen sus sillares y que define el grupo considerado «visigodo» formado por Quintanilla y la Nave, al que unimos Melque, pese a la diferencia que provoca la utilización del material de granito que obliga a la existencia de desdobles de hiladas. En este grupo, los desdoblamientos son excepcionales y los codos reducen tanto su tamaño que apenas son distinguibles. El cuarto grupo, que enlaza con un nuevo horizonte, reduce drásticamente el tamaño de los si- llares que están escuadrados y colocados en hiladas horizontales (Escalada, cabecera y pórtico, y Tobillas/2). Las hiladas de sillería se regularizan en Montelios, con el mismo número de hiladas a interior y exterior, sin saltos, ni codos; el pórtico de Valdediós, Celanova o la parte original de Zalduendo ${ }^{6}$.

$\mathrm{Al}$ margen de esta posible ordenación tipológica, aun carente de su valoración cronológica, podemos hacer referencia a algunos otros caracteres que son también típicos de una parte significativa de nuestros ejemplos.

La reutilización de sillares (sea de expolio o procedente del edificio arruinado y en restauración) obliga a su recorte para regularizarlos y ajustarlos a su nueva posición y, por lo tanto, al cambio de su proporción (más alargado en el caso del granito, Bande) y la disminución de su módulo (Arlanza, la Asunción). Éste es también normalmente inferior en las hiladas superiores, tal vez como reflejo de las dificultades de elevación de los sillares y debido a razones estructurales, buscando un asiento más seguro de los muros. Así ocurre en Suso/2, Baños y la Nave. En el último ejemplo, la mayor frecuencia de tizones pasantes en las hiladas inferiores pueda posiblemente también explicarse por la misma razón tectónica.

Una característica generalizada en los edificios de sillería hispanos (ya notada por GÓMEZ MORENO 1919 en Suso comparada con Melque) es el de la ondulación de las hiladas debido a la falta de horizontalidad de sus lechos de asiento. Esta característica va unida a la oblicuidad de las caras laterales de los sillares (que llegan a adoptar forma de "clave», la Nave), a la repetición de codos y los desdoblamientos de hiladas. La inclinación de las hiladas y la irregularidad de los sillares indica el uso de la regla en la talla primaria, pero no de la escuadra, dada la ausencia de ángulos rectos y, quizás, la talla final de los sillares a pie de obra o sobre el andamio para posibilitar el perfecto ajuste de las caras de cada sillar con las de los ya colocados.

Las juntas de los sillares se efectúan a hueso en los paramentos exteriores, pero suelen mostrar juntas mayores en el interior que a veces hacen sospechar que se trata de fábricas diferentes. Se pueden comparar las caras interiores y exteriores de Suso para constatar tal diferencia. No ocurre así, por ejemplo, en Quintanilla, donde la talla de la sillería de arenisca y el terminado cuidado de ésta tanto en superficie como en juntas, se mantiene al exterior y al interior.

\footnotetext{
${ }^{6}$ Desestimamos aquí las iglesias de Balsemão, que debe considerarse una recreación arquitectónica de época moderna (CABALlERO y ARCE 2004), y Lourosa, profundamente afectada por las labores de restauración, desmonte y remonte llevadas a cabo en los años treinta (AgUIAR 1934), lo que nos hace dudar de la originalidad y contemporaneidad de distintas partes de la iglesia.
} 
A partir de estas observaciones y teniéndolas en cuenta podemos intentar acercarnos a la cronología cruzada de la estratigrafía en los casos en que se asegura la continuidad de construcción en la alta Edad Media. En tres edificios parece mantenerse la técnica de taller, Melque/2 (habitación trasera añadida), Arlanza/2 y la Asunción/2y3 (reconstrucción tras ruinas provocadas por colapso del abovedamiento), de modo que el nuevo aparejo depende del anterior aunque en los dos últimos casos limitados por el recorte de la reutilización del mismo material. En otros edificios, de mayor interés, existe un cambio de aparejo que indica un cambio de taller productivo. Tres de ellos «mejoran" al cambiar a sillería regularizada: Tobillas/2 (939), Escalada (cabecera y pórtico) y Valdediós/2 (pórtico, 910). Dos en cambio «empeoran», pasando de la sillería al sillarejo: Tricio/2 (naves) y la Asunción/4 (restauración final del ábside y añadido del pórtico). Los casos de la Asunción y Valdediós nos hicieron pensar si estos referentes son signo de un cruce de influencias. Los casos de Valdediós y sus compañeros podrían suponer la llegada desde talleres meridionales (¿del valle del Duero?) de la sillería al mundo asturiano y, al contrario, los de la Asunción y Tricio, el influjo de talleres tardíos asturianos.

\section{La talla}

Aunque el instrumental parece similar en la mayoría de los casos estudiados, bien azuela ${ }^{7}$, bien cincel de hoja plana, se aprecian diferencias (fig. 5). El edificio de Suso/2 puede servir de ejemplo. El tipo de acabado entre las caras exteriores e interiores es notablemente diferente, con una sillería a hueso muy bien acabada en el primero y una sillería de juntas peor ajustadas en el segundo, aunque los marcos de los arcos poseían un perfecto acabado. El que por razones que desconocemos se interrumpiera sin acabar la talla exterior del edificio permite detallar su proceso. Los sillares se colocaban tal como venían de cantera (no hay indicio de que procedieran de expolio), con sus irregularidades que sobresalían entre 3 y más de $5 \mathrm{~cm}$. sobre la superficie definitiva y que les daba un aspecto de sillería «almohadillada». Estas irregularidades se labraban una vez acabado el edificio, inmediatamente antes de desmontar los andamios, utilizando para ello la azuela. Este proceso viene demostrado porque la huella de desbastado de la herramienta pasa de sillar a sillar, indicando que el acabado es posterior a la puesta en

\footnotetext{
7 Venimos utilizando este nombre, sin demasiado rigor, para una herramienta que Leandro Sánchez Zufiaurre (al que agradecemos sus datos), a partir de los estudios que actualmente realiza sobre tipología constructiva en Álava, identifica con un cincel de filo cóncavo o "gubia de cantero" y que también podríamos confundir con una piqueta de cantero.
}

obra; por la presencia de guías verticales talladas a intervalos regulares de unos $30 \mathrm{~cm}$. entre sí, con un ancho de unos $5 \mathrm{~cm}$., que recorren los alzados pasando de hilada a hilada; y porque no se han rebajado algunas superficies irregulares previas y, en lo alto de los paramentos externos, se han dejado protuberancias a medio tallar en el arranque de las calles de desbastado (¿quizás los puntos en que se apoyaban los andamios?). El instrumento de talla recibe un uso diferencial según la zona de la fábrica en que se aplica: frontalmente en los muros, originando una huella lineal, profunda y corta, y de plano en los marcos de los arcos y en las superficies de los fustes, dando lugar a una superficie prácticamente lisa de huella prolongada y aspecto pulido.

El acabado de la superficie de los sillares una vez colocados en obra justifica que la zona baja de los paramentos quede sin rematar, presentando un aspecto grosero e irregular, a veces con la huella de la herramienta usada para la desbastación. Así ocurre en las iglesias de sillería de Suso, la Nave, Bande, Melque o el pórtico meridional de Escalada. Visibles tanto al interior como al exterior, sirven de indicativo del nivel original del suelo de obra.

En Baños/1 tampoco se reconocen las guías, pero la talla (a cincel) de la sillería arenisca es pasante, indicando su retalle final. A diferencia de Suso/2, en Arlanza/1a las guías se documentan individualmente en las esquinas de cada sillar, reflejo de un careado independiente de los sillares antes de ser colocados en el muro. En la Nave/1 se emplea una herramienta análoga al hacha (escoda) o la azuela que deja una huella semejante en la viga y las grapas de madera. Como en Arlanza, la huella no es pasante, lo que, junto a las guías visibles en algunas aristas y la dirección en abanico de las huellas, aboga por un acabado a pie de obra. En Tobillas la diferencia material e instrumental contribuye a la diferenciación estratigráfica: Prerrománico I, sillería de arenisca reutilizada retallada a azuela, y Prerrománico II, sillería arenisca de cantera tallada a cincel. Lo mismo ocurre en $\mathrm{Suso} / 3$ donde los paramentos protorrománicos tallan los sillares individualmente, dejando guías en las aristas y luego vaciando toda la cara, empleando para ello una herramienta diferente, un cincel.

En iglesias como Bande, Montelios, Melque, la Portera o los Fresnos, la naturaleza granítica del material impide reconocer las huellas de talla y retalle.

La ausencia de talla del paramento interior en las iglesias de Arlanza, Tricio y Sta. Coloma se debe a que estas caras iban a recubrirse con una gruesa capa de estuco de la que quedan indicios en la primera de ellas y evidentes restos decorados en la tercera. Un caso parecido puede ser el de Nazaré donde, recubriendo sus muros de mampostería, se conservan indicios de estucos interiores con decoración 


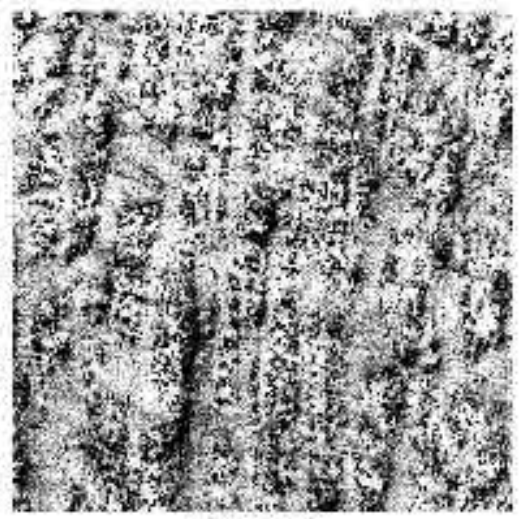
SUISO $/ 1$

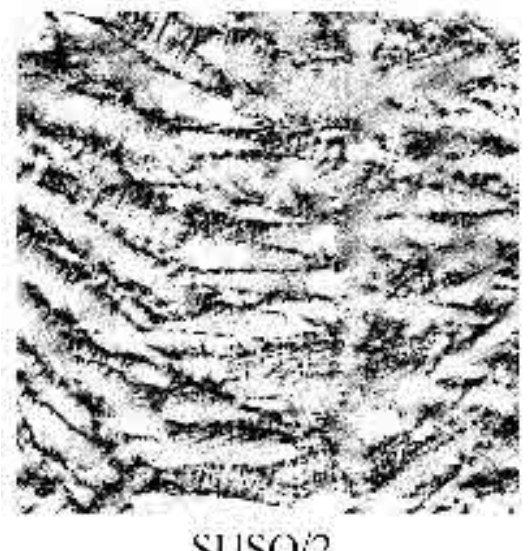

$$
\text { SUSO/2 }
$$

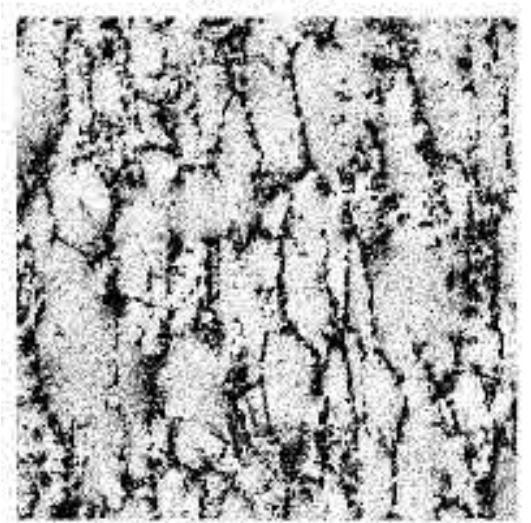

$$
\text { BAÑOS:1 }
$$

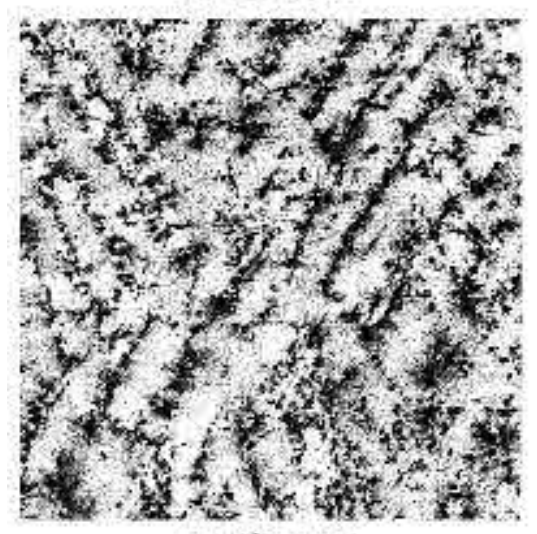

$$
\text { BAÑOS:1 }
$$

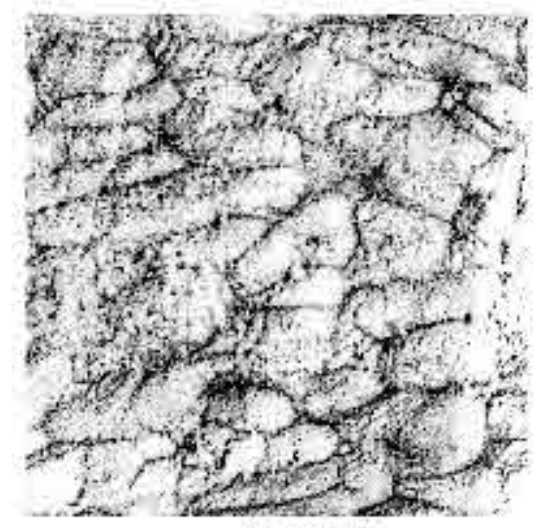

$\mathrm{SUSO} / 2$

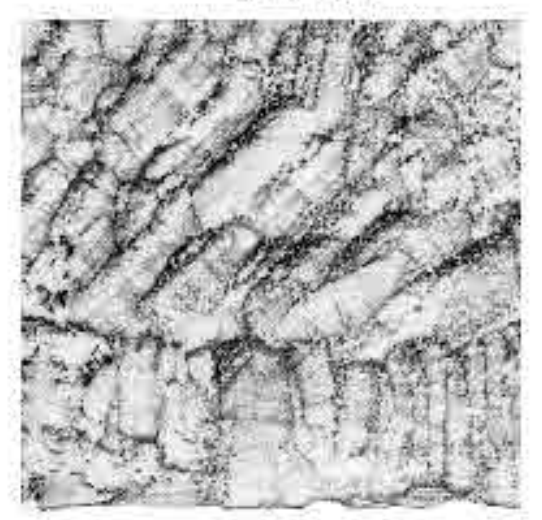

$\mathrm{SUISO} / 3$

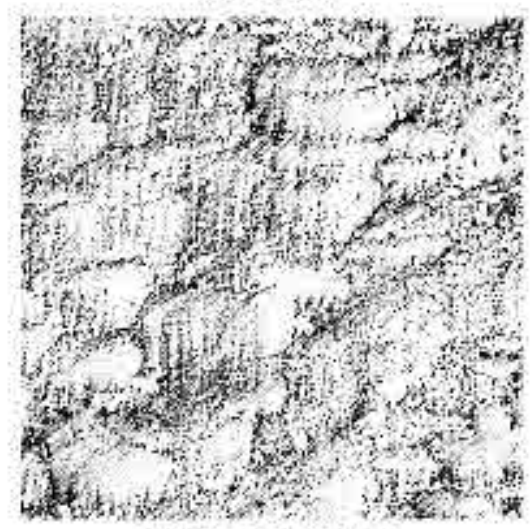

$$
\text { FSCAI.ADA/1 }
$$

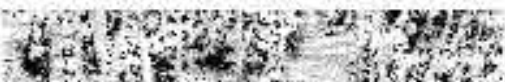

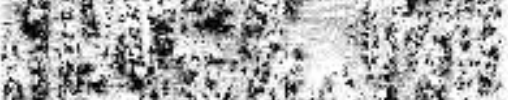

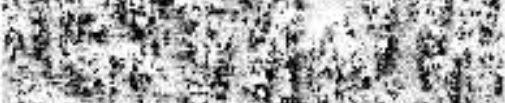
7.

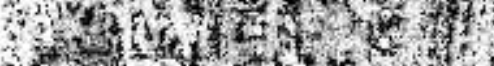

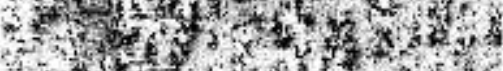

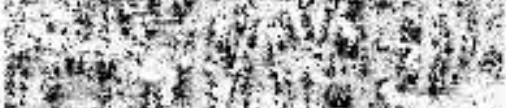

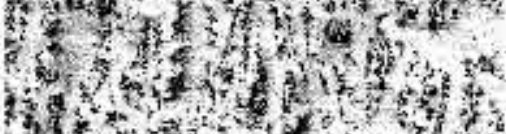

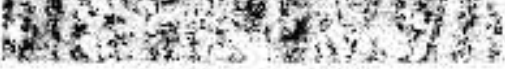

$$
\text { F.SCAI AI)A/2 }
$$

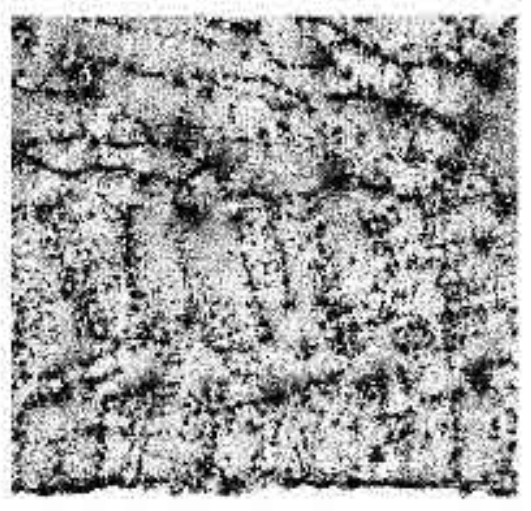

$\mathrm{NAVE} / 1$

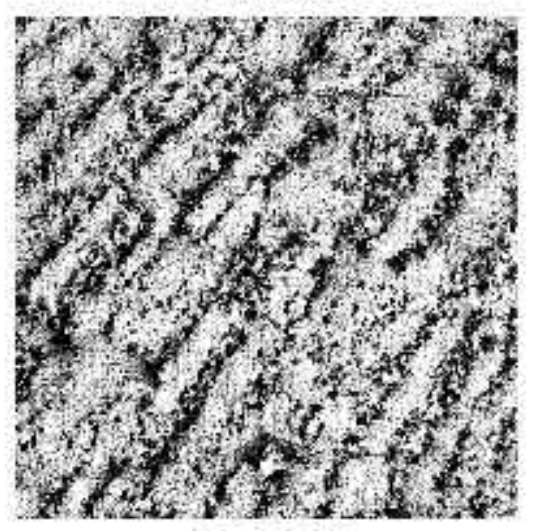

NAVE/I

[scala: $1 / 2$

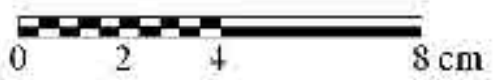

Figura 5. Tipología de tallas de sillería. E. 1/2 
estampada. Puede ser que la irregularidad observada en las iglesias de Suso y la Nave fuera debida a que sus caras internas iban enfoscadas, aunque el perfecto acabado de la talla en los marcos de los arcos de la de Suso podría indicar que estos quedaban reservados. En Quintanilla, la ausencia de capiteles en las columnas del arco de triunfo podría deberse a que los tuviera de estuco, pero el acabado de sus paredes invita a pensar que eran vistas. En Melque quedan indicios de la cubierta de estucos moldeados y tallados en su cimborrio y sus arcos (¿quizás también en el anteábside y el ábside?), mientras que las demás naves sólo tenían un encintado en las juntas de los sillares. De todos es conocido el acabado revocado y pintado de las iglesias asturianas (Santullano, Valdediós, Liño, Priesca, Tunón) cubriendo sus paramentos normalmente de mampostería o sillarejo. También los paramentos interiores y exteriores del Trampal, debido a su aparejo de mampostería, estaban cubiertos con una doble capa de enlucidos, la inferior de las cuales se aprovechó para grabar un grafito en obra.

Como hemos indicado al comienzo, la visión tradicional defiende una evolución desde la mampostería, pasando por la mampostería encadenada con sillería reutilizada o ex novo hasta llegar a la sillería. La sillería de cantero no aparecería hasta el siglo VII, concretamente en la segunda mitad, pero ya en el siglo VI se producirían grandes bloques decorados o sillares esquineros y columnas o pilares (HAUSCHILD 1972) que influirían en la recuperación de la técnica de sillería del mundo romano. Frente e esta hipótesis entendida dentro del marco de continuidad tipológica, de nuevo debemos remitir la pregunta a la técnica: ¿̨se puede recuperar una técnica perdida por simple evolución o es necesario un aprendizaje de ésta, en cuyo caso debe pensarse en un motor externo? La segunda opción es defendida por el nuevo modelo, quien haya en la experiencia islámica el motor que justifica la aparición de la sillería y, del mismo modo, de otros tantos cambios que dan lugar a una nueva arquitectura a partir del siglo VIII.

\section{CONOCIMIENTO ESTRUCTURAL}

La combinación de cubiertas de madera y abovedadas en iglesias que pertenecen al mismo grupo constructivo o incluso a la misma iglesia (Baños, Santullano, las mozárabes Suso, Escalada, Mazote, entre otras) dibuja un paisaje variado en soluciones estructurales en el que la novedad, respecto al momento tardorromano, en cualquier caso, es la bóveda y los empujes que provoca (fig. 6). El principal interés por la investigación de las cubiertas de las iglesias de piedra de este momento reside en la discusión sobre si mayoritariamente estuvieron cubiertas de madera o, al contrario, si lo estuvieron con bóvedas de sillería, y en la tradición y procedencia de estos sistemas. La cronología alto medieval, sin embargo, no presupone la existencia de una mano de obra altamente cualificada, que conozca todos los recursos técnicos, sino, más bien, la imitación o la repetición mecánica de modelos de los que parece desconocerse en gran parte su verdadero funcionamiento. Tampoco se puede suponer en sentido estricto como un momento de tentativas y pruebas, pues parece que los modelos o son en su mayoría únicos o, en el caso excepcional de que se repitan, lo hacen con las mismas características, siendo difícil establecer, en el estado actual de nuestros conocimientos, una secuencia de mejoras técnicas. Debemos tener en cuenta la reiterada documentación de ruinas debidas a las estructuras abovedadas, en ocasiones inmediatas al momento de la construcción como demuestra su restauración también alto medieval (Arlanza y la Asunción, además el Trampal, la Nave, Quintanilla; también Suso, aunque por un incendio fortuito, no estructural).

Hemos de valorar la relación existente entre los caracteres a los que hasta ahora nos hemos referido y la estructura a la que estaban destinados. En el Trampal llama la atención, en este sentido, el aparejo de mampostería y sillería de expolio dedicada a sostener una estructura completamente abovedada y las soluciones que, quizás por ello, se emplearon, con su paralelo en el mundo asturiano en Valdediós, con una solución que evidentemente dio mejor resultado. Otro caso a valorar es el de estructuras similares, como suponemos eran las del grupo burgalés/riojano, ajustadas al modelo de ábside cuadrado con bóveda sobre pechinas y aula de tres naves abovedadas, construidas en toda la gama de aparejos conocidos, aunque manteniendo la unidad de la piedra toba para la construcción de la vaída. En este caso podría pensarse en la existencia de dos grupos o talleres distintos de expertos, uno más local del que dependía la variabilidad del aparejo, y otro más regional que mantenía la técnica de las bóvedas vaídas; expertos que sabían conjuntarse para realizar un trabajo unitario. Equipos que además admitían la presencia de escultores, estucadores y mosaistas (Quintanilla, la Asunción, Arlanza, Tricio, Sta. Coloma). La riqueza de tipos de aparejos y la simplicidad de modelos estructurales del grupo burgalés/riojano contrasta con la aparente simplicidad del aparejo asturiano donde sin embargo conocemos un mayor abanico de modelos estructurales cuyo resultado tuvo evidente éxito. Circunstancias sociales, políticas y económicas influyeron en estas distinciones.

El uso de la pechina para salvar espacios cuadrados, normalmente de reducidas dimensiones (ábsides), en material ligero como la toba tanto en el elemento de transición como en la hemiesfera, habla de una utilización selectiva del material: caliza tobácea de escaso peso cuyos empujes son conducidos por las pechinas. Melque, constituye la ex- 

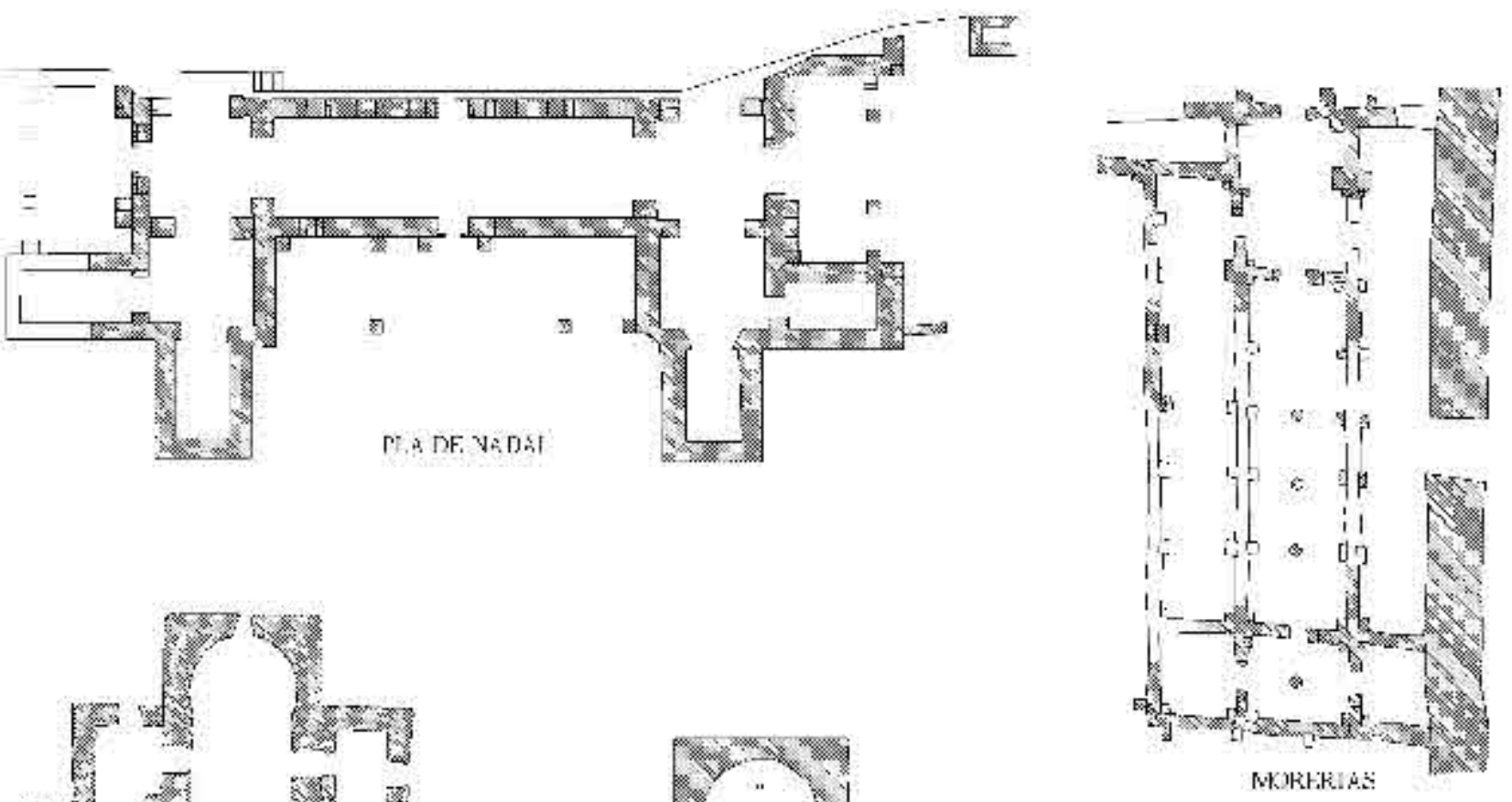

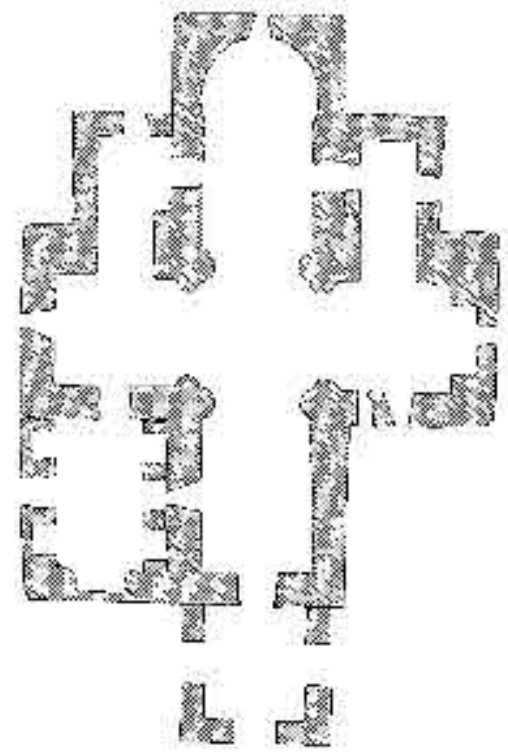

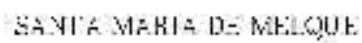

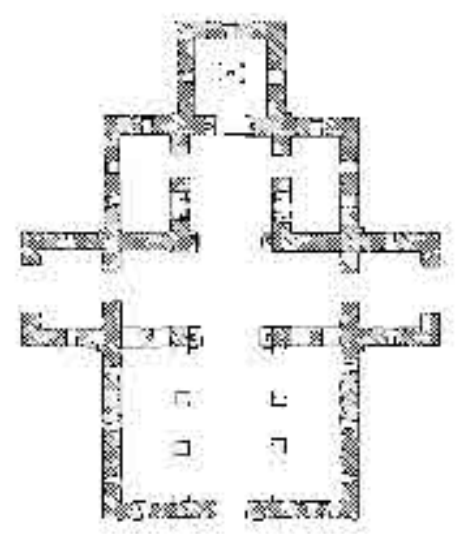

$\triangle A N$ PEDO DE LA MSYE
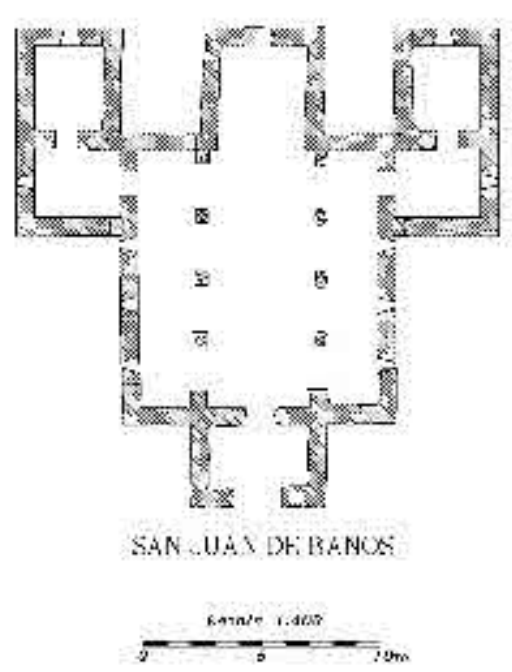

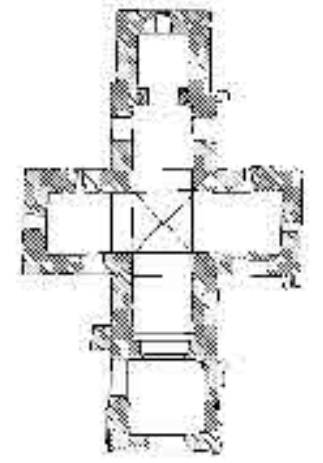

SANTA CONPA LE BAYDE

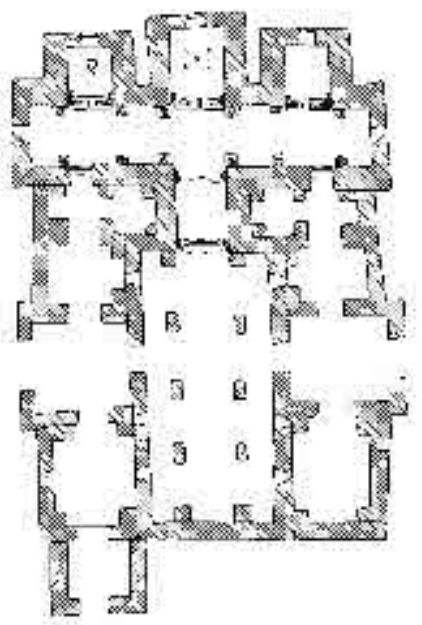

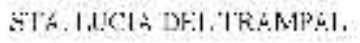

Figura 6. Plantas de algunos de los edificios citados. E. 1/400 

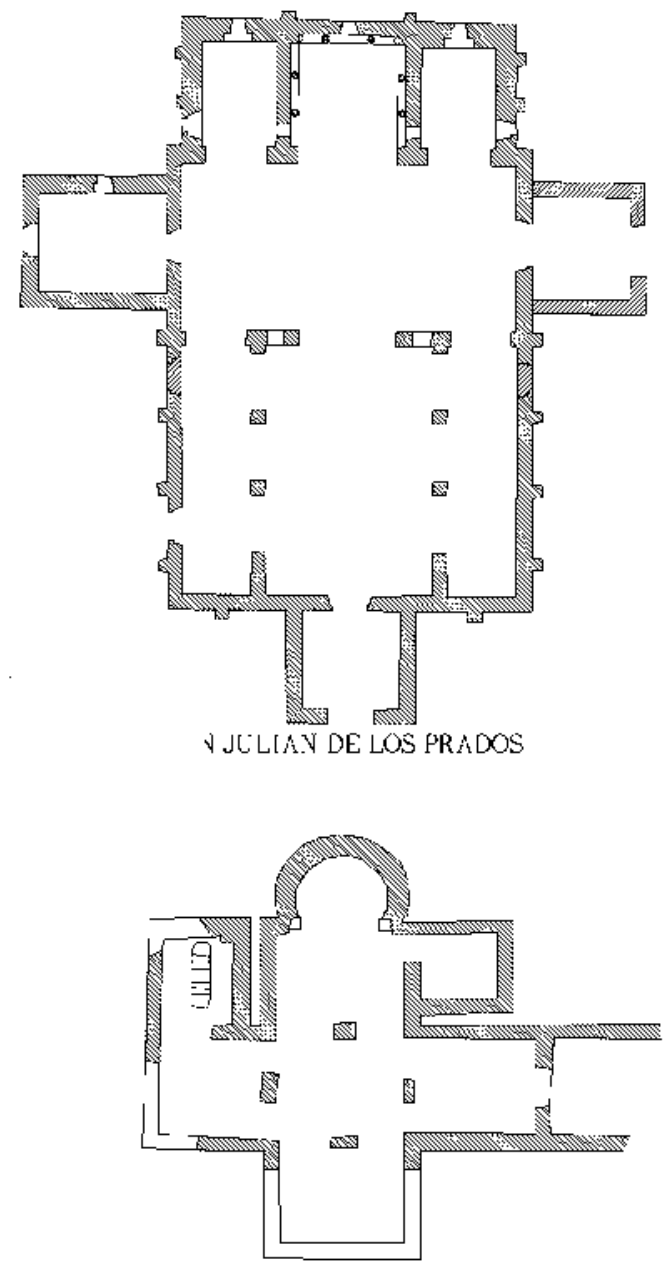

WALEECEBADAR

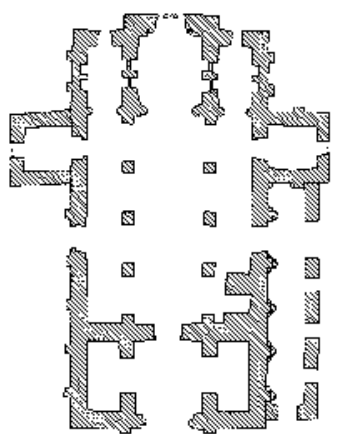

VALDEDIOS

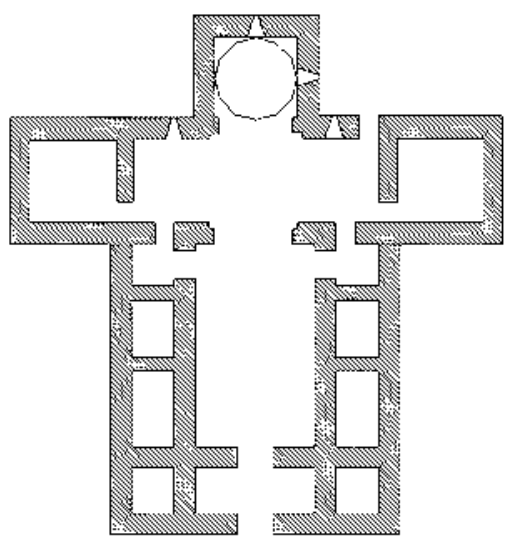

QUINTANILLA DE LAS VAAS
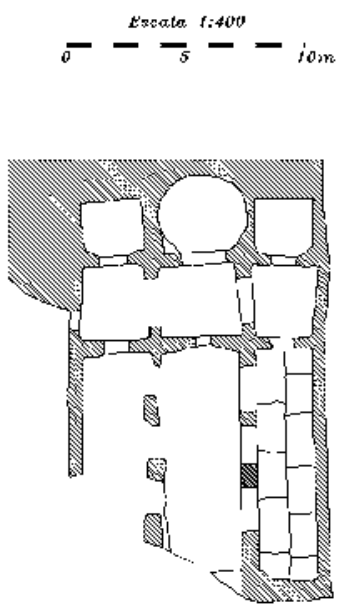

BOBAsTRO

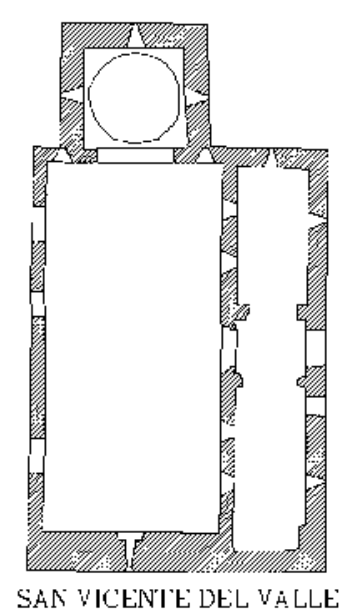

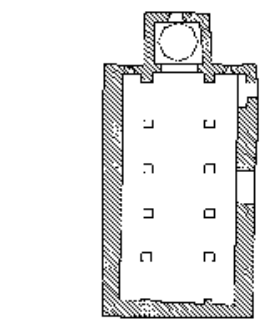

SAN PEDRO DE ARLANEA

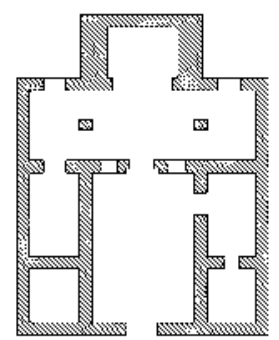

NA ZARE:
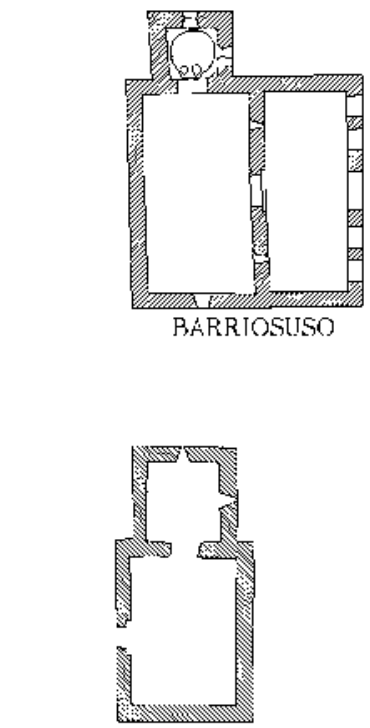

SAN ROWAN DE WMOROSO

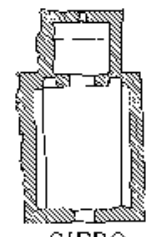

SIERO
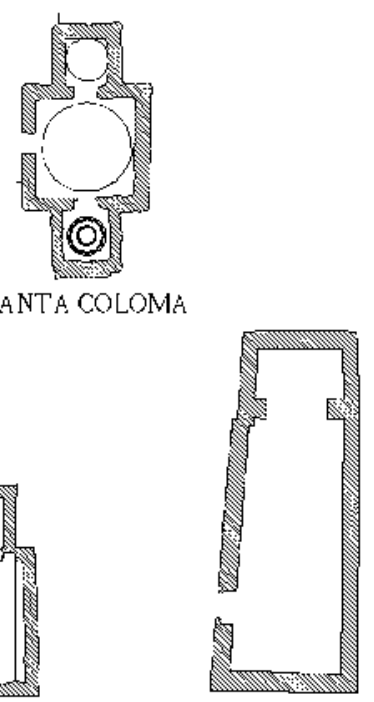

BARBA DILLO

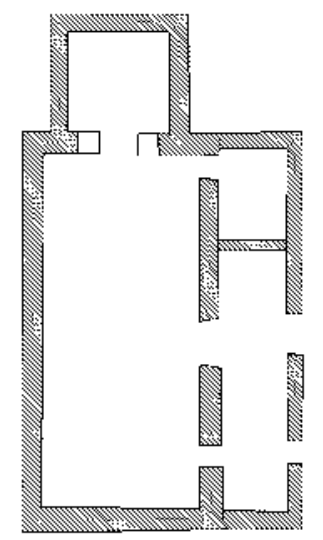

SAN MIGUEL DE GORMAZ 
cepción en piedra, pero se trata de una cúpula falsa, tallada en sus primeras hiladas dispuestas horizontalmente, lo que reduce a un tercio la bóveda real. Como también hemos indicado, el uso del ladrillo se da mayoritariamente en las estructuras abovedadas.

Los sillares doblados en puntos débiles de las fábricas actúan como elementos de refuerzo e indican un mínimo conocimiento estructural. De hecho encontramos muros, que aunque en su parte baja no aten mediante piezas únicas, sí lo hacen en las partes altas, las más próximas a los abovedamientos. Los sillares doblados de las hiladas situadas entre los arcos de herradura y las molduras de las cúpulas de Suso, los sillares comunes que unen bóveda y arco del ábside de la Nave o los sillares de caliza inferiores de las pechinas de la Asunción pueden servir de ejemplo. También hallamos este tipo de piezas en las esquinas interiores de los muros, en Melque (también columnas interiores del crucero), Quintanilla, Bande y la Nave. Junto a ellos, debemos incluir las grapas y los zunchos de madera de la Nave como elementos de cohesión. En el caso de las fábricas de mampostería, las cadenas de esquina y las verdugadas de ladrillo o de sillería responden a la funcionalidad de atado de los muros perimetrales, no solamente al reforzamiento por la presencia de estructuras abovedadas. Por otro lado, estructuras abovedadas como el ábside de las Ollas o los espacios de Peñalba, no poseen sillares esquineros, posiblemente innecesarios por el tipo de cúpula empleado (de gallones), las dimensiones murarias y la sucesión escalonada de los espacios.

El empleo de contrafuertes y sistemas de contrarresto tiene un desarrollo delimitado. Las iglesias asturianas combinan frecuentemente contrafuertes exteriores con arcos ciegos interiores, aunque en algunos casos no se corresponden (Liño, Naranco, Lena). Las reducidas dimensiones, la altura sobrepasando la línea de arranque de las bóvedas y la disposición «aleatoria» hace dudar de su uso único como contrarresto: tal vez posean una función más de refuerzo de los altos muros de mampuesto. Ello lo confirmaría el hecho de que también se encuentren no solamente vinculados a espacios abovedados, sino a aulas cubiertas con techumbres de madera (Santullano, Nora, Gobiendes). Contrafuertes vinculados a bóvedas de medio cañón los hallamos en Celanova y Wamba, realizados en sillería, como el resto de la fábrica; y Peñalba, donde se ejecutan en la misma mampostería que los muros ${ }^{8}$. El caso del

${ }^{8}$ Los problemas de adscripción cronológica de Santa Olalla (Cáceres) y Vera Cruz de Marmelar (Portugal; CABALLERO y ARCE 2004), en las que los contrafuertes se disponen anómalamente en el testero de sus ábsides abovedados y el material decorativo esta reutilizado, nos impide incluirlos en este trabajo.
Trampal es distinto, quizás en la misma línea de algunos casos asturianos y de soluciones del románico lombardo. No posee contrafuertes en sentido estricto, aunque el movimiento de la planta en cabecera o el adosamiento de los arcos (arcos ciegos) de los cuerpos laterales pueden significar un intento similar, no solo de contrarrestar los empujes de las bóvedas, sino de cohesionar una fábrica de indudable pobreza.

\section{CONCLUSIONES}

Un intento de síntesis de los datos ofrecidos en este trabajo puede resultar heterogéneo y confuso, dada la variedad y dispersión cronológica y geográfica de los monumentos tratados. La impresión ofrecida es la de edificios singulares aislados o aparejos que no se agrupan de un modo homogéneo con las soluciones estructurales. Responden a esta visión, tradicional, ejemplos como el Trampal, Melque, Montelios, Nazaré, Baños, la Nave, Liño o el Naranco. Pero, a la vez, también conseguimos la sensación de la existencia de grupos geográficos donde o referentes de aparejos o de estructuras pueden hablarnos de talleres (grupos asturiano y burgalés/riojano, y quizás mozárabe, galaico y lusitano). Tampoco debemos olvidar las posibles relaciones o influjos a larga distancia o de largo tiempo. La dispersión de ejemplos únicos, que impediría defender la existencia de talleres asentados, provoca pensar en una solución muy distinta, en un momento favorable a la afluencia con cierta profusión de modelos abundantes y de la dispersión y el movimiento de los expertos; solución que se podría vincular al concepto de "frontera abierta» propuesta por MANZANO (1991), que apoyaría el modelo explicativo que ve el surgimiento de esta arquitectura en la revolución omeya. Sin embargo, esta solución obliga a buscar modelos en las fuentes de procedencia, pues tampoco sería defendible el invento autónomo de aparejos y soluciones estructurales. En último lugar, no debemos olvidar otra variable, la temporal, situada en el centro de la polémica entre los modelos a que nos referimos. La datación de estos edificios no debe perseguirse a priori sólo por el modelo explicativo, sino que debemos acoplarlos también a las fechas que los diversos tipos de análisis nos consigan (no sólo arqueométricos; pues son también válidos los conseguidos correctamente por métodos tipológicos, epigráficos o estilísticos). Y algunos de estos datos analíticos, por ahora, parecen contradecir el modelo omeya.

De esta forma, el panorama que obtenemos es muy heterogéneo, pero ¿lo es realmente o nuestro desconocimiento científico impide todavía crear grupos tecnológicos definidos?, ¿ya estamos en condiciones de ajustar un abanico de fechas aceptables al panorama apuntado?, ¿estamos 
en posición de ofrecer resultados concluyentes?, ¿podemos hablar de producción arquitectónica a partir de los datos que poseemos?, ¿y de organización del trabajo?

La línea evolutiva defendida por la teoría tradicional en torno a un paso «natural» desde la mampostería a la sillería o desde las cubiertas de madera a las soluciones abovedadas, encierra detrás del mero estudio tipológico la cuestión sobre la autoría de la arquitectura: talleres constructivos y decorativos y su organización. Por otro lado, no se aprecia una evolución neta de las técnicas. Parecen funcionar talleres o grupos caracterizados, pero todavía no están definidos. Nuestra próxima meta ha de ser la de definición de talleres, consecuente con una depuración de nuestra metodología (estratigrafía y tipología), con el desarrollo de un análisis pormenorizado de los monumentos (proyectos de investigación) y la consecución de fechas aceptables (arqueometría). 


\begin{tabular}{|c|c|c|c|}
\hline Nombre & Adscripción cronológica & Criterios & Bibliografía \\
\hline 70. Alberca, La & $\begin{array}{l}\text { Paleocristiana, s.vI } \\
\text { Mediados s. IV }\end{array}$ & Excavación, tipología & $\begin{array}{l}\text { Mergelina } 1947 \\
\text { Palol } 1967\end{array}$ \\
\hline 3. Ambía & Mozárabe, S. x & Estilo & Núñez 1978 \\
\hline 46. Arlanza/1, Arlanza/2 & (912) Reconquista, s. Ix & Estratigrafía, tipología & Caballero y otros 1994 \\
\hline $\begin{array}{l}\text { 44. Asunción/1, La } \\
\text { Asunción/2 } \\
\text { Asunción/3 } \\
\text { Asunción /4 }\end{array}$ & $\begin{array}{l}\text { Visigodo, s. VI } \\
\text { (934-945) Reconquista, s. } \mathrm{x}\end{array}$ & $\begin{array}{l}\text { Excavación } \\
\text { Estratigrafía, tipología }\end{array}$ & $\begin{array}{l}\text { Aparicio y Fuente } 1996 \\
\text { Arce } 1998\end{array}$ \\
\hline 52. Balsemão & $\begin{array}{l}\text { Visigodo, s. VII } \\
\text { Mediados s. IX }\end{array}$ & $\begin{array}{l}\text { Tipología } \\
\text { Técnica }\end{array}$ & $\begin{array}{l}\text { Schlunk y Hauschild } 1978 \\
\text { Ferreira } 1986\end{array}$ \\
\hline 6. Bande & $\begin{array}{l}\text { (672; aq 872), visigodo } \\
\text { Reconquista, s. IX }\end{array}$ & $\begin{array}{l}\text { Documentación, estilo } \\
\text { Estratigrafía, tipología }\end{array}$ & $\begin{array}{l}\text { Schlunk y Hauschild } 1978 \\
\text { Caballero 1994/95 }\end{array}$ \\
\hline 38. Baños & $\begin{array}{l}(661) \text { visigodo } \\
\text { Reconquista, circa } 900\end{array}$ & $\begin{array}{l}\text { Epigrafía, estilo } \\
\text { Estratigrafía, tipología }\end{array}$ & $\begin{array}{l}\text { Schlunk y Hauschild } 1978 \\
\text { Caballero y Feijoo } 1998\end{array}$ \\
\hline 47. Barbadillo & $\begin{array}{l}\text { Visigodo, s. VII } \\
\text { s. XI }\end{array}$ & $\begin{array}{l}\text { Tipología } \\
\text { Tipología }\end{array}$ & $\begin{array}{l}\text { Osaba } 1968-72 \\
\text { Arbeiter y Noack } 1999\end{array}$ \\
\hline 66. Barcelona, iglesia cruciforme & Visigodo, fin s. VI & Excavación & Bonnet y Beltrán 2001 \\
\hline 48. Barriosuso & (924) Reconquista, S. x & Estratigrafía, tipología & Caballero 1994/95 \\
\hline 11. Bendones & Asturiano $1 . \mathrm{a} / 2 \mathrm{~s} . \mathrm{IX}$ & Tipología & Arias 1993 \\
\hline 51. Berlanga & $\begin{array}{l}\text { Mozárabe, principios XI } \\
\text { Mozárabe, } 3 / 4 \text { s. XI }\end{array}$ & $\begin{array}{l}\text { Estilo } \\
\text { Carbono } 14 \\
\end{array}$ & $\begin{array}{l}\text { Zozaya } 1976 \\
\text { Alonso y otros } 1997\end{array}$ \\
\hline 73. Bobastro & (889/917) Mozárabe & Documentación, tipología & Puertas 1979 \\
\hline 2. Bóveda/1 y/2 & $\begin{array}{l}\text { Paleocristiano, s. IV-V } \\
\text { Reconquista }\end{array}$ & Tipología & Núñez 1978 \\
\hline 42. Buradón & Mozárabe, mediados s. x & Excavación & Unzueta y Martínez 1994 \\
\hline 14. Cámara Santa, La & Asturiano, $1 .{ }^{\mathrm{a}} / 2 \mathrm{o} 2 .^{\mathrm{a} / 2 \mathrm{~s} . \mathrm{IX}}$ & Documentación, tipología & Arias 1993 \\
\hline 5. Celanova & (942) Mozárabe s. x & Epigrafía, tipología & Núñez 1978 \\
\hline 62. Fresnos, Los & Visigoda & Tipología & Berrocal y Caso 1991 \\
\hline 49. Fuentearmengil & Mozárabe & Tipología & Caballero y Arce 1997 \\
\hline 72. Gabia la Grande & Tardo romano, s. vI $(\dot{\xi})$ & Tipología & Gómez Moreno 1949 \\
\hline 56. Gatillo, El & Tardo romano/alta EM, s. vi/IX & Excavación & Caballero y otros 1991 \\
\hline 20. Gobiendes & Asturiano $4.0 / 4$ s. IX & Documentación & Arias 1993 \\
\hline 50. Gormaz & Mozárabe, s. XI & Excavación & Heras y otros 2001 \\
\hline 9. Guimarães & Reconquista, s. x (931-51) & Decoración & Real 1995 \\
\hline 39. Hérmedes & Mozárabe, s. X & Decoración & Escudero 1942-43 \\
\hline 21. Lebeña & Mozárabe, s. x (aprox. 930) & Decoración, tipología & Gómez Moreno 1919 \\
\hline 16. Lena & Asturiano, mediados s. IX & Tipología & Arias 1993 \\
\hline 12. Liño & (848) Asturiano & Epigrafía, documentación, tipología & Arias 1993 \\
\hline 53. Lourosa & (912) Mozárabe, s. x & Epigrafía, tipología & Gómez Moreno 1919 \\
\hline 33. Marialba & Paleocristiano, s. IV/viI & Excavación & Hauschild 1968 \\
\hline 55. Marmelar & $\begin{array}{l}\text { Visigodo s. VII } \\
\text { ¿? }\end{array}$ & $\begin{array}{l}\text { Decoración } \\
\text { Decoración reutilizada }\end{array}$ & $\begin{array}{l}\text { Schlunk y Hauschild } 1978 \\
\text { Caballero y Arce } 2004\end{array}$ \\
\hline 65. Mata, La & $\begin{array}{l}\text { Visigodo } \\
\text { 1.er mozárabe, 2.a/2 s. IX }\end{array}$ & $\begin{array}{l}\text { Documentación, tipología } \\
\text { Tipología }\end{array}$ & $\begin{array}{l}\text { Schlunk y Hauschild } 1978 \\
\text { Caballero 1994/95 }\end{array}$ \\
\hline 35. Mazote & (916) Mozárabe, principios s. $\mathrm{x}$ & Documentación, tipología & Gómez Moreno 1919 \\
\hline 64. Melque & $\begin{array}{l}\text { Mozárabe, s. x } \\
1 .^{\text {er }} \text { mozárabe, } 2 .{ }^{a} / 2 \mathrm{~s} \text { VIII }\end{array}$ & $\begin{array}{l}\text { Tipología } \\
\text { Excavación, arqueometría }\end{array}$ & $\begin{array}{l}\text { Gómez Moreno } 1919 \\
\text { Caballero y Fernández } 99\end{array}$ \\
\hline 41. Mijangos & Tardo romano/alta EM ss. v/viII & Excavación, c-14, epigrafía & Lecanda 1999 \\
\hline 7. Mixos & Mozárabe, s. x & Tipología & Núñez 1978 \\
\hline
\end{tabular}

Figura 7. Tabla con la lista de edificios citados, con sus fechas y adscripciones 


\begin{tabular}{|c|c|c|c|}
\hline Nombre & Adscripción cronológica & Criterios & Bibliografía \\
\hline 8. Montelios & $\begin{array}{l}\text { (656/665) Visigodo } \\
\text { Reconquista, s. Ix }\end{array}$ & $\begin{array}{l}\text { Documentación, tipología } \\
\text { Estratigrafía, tipología }\end{array}$ & $\begin{array}{l}\text { Schlunk y Hauschild } 1978 \\
\text { Real } 1995\end{array}$ \\
\hline 60. Morería, residencias & Muladí, andalusí, 2.a/2 s. viII & Excavación & Mateos y Alba 2000 \\
\hline 22. Moroso & Mozárabe, s. x & Tipología & Gómez Moreno 1919 \\
\hline 13. Naranco, El & Asturiano mediados s. IX & Tipología, documentación & Arias 1993 \\
\hline 34. Nave, La & $\begin{array}{l}\text { Visigodo, 2.a/2 s. vII } \\
(878-893) \text { Reconquista, s. IX }\end{array}$ & $\begin{array}{l}\text { Estilo } \\
\text { Excv, estrtgrf., tiplg., arqmt. }\end{array}$ & $\begin{array}{l}\text { Schlunk y Hauschild } 1978 \\
\text { Caballero y Arce } 1997\end{array}$ \\
\hline 54. Nazaré & $\begin{array}{l}\text { Visigodo, 2.a/2 s. VII } \\
\text { Reconquista, s. x (931-51) }\end{array}$ & $\begin{array}{l}\text { Estilo } \\
\text { Historia, estratigrafía, tipología }\end{array}$ & $\begin{array}{l}\text { Schlunk y Hauschild } 1978 \\
\text { Real } 1995\end{array}$ \\
\hline 17. Nora & Asturiano, $1 . \mathrm{a} / 2 \mathrm{~s} . \mathrm{IX}$ & Tipología & Arias 1993 \\
\hline 43. Oca & $\begin{array}{l}\text { Visigodo, s. viI } \\
\text { (863) Reconquista, s. Ix }\end{array}$ & Tipología & $\begin{array}{l}\text { Schlunk y Hauschild } 1978 \\
\text { Caballero 1994/95 }\end{array}$ \\
\hline 30. Ollas, Las & Mozárabe, s. x & Tipología, relación doc. 919 & Gómez Moreno 1919 \\
\hline 4. Pazó & Mozárabe, s. x & Tipología & Núñez 1978 \\
\hline 31. Peñalba & (937) Mozárabe, s. x & Documentación, tipología & Gómez Moreno 1919 \\
\hline 68. Pla de Nadal & $\begin{array}{l}\text { Visigodo, 2.a/2 s. VII } \\
\text { Andalusí, 2.a/2 s. VIII }\end{array}$ & Excavación, tipología & $\begin{array}{l}\text { Juan y Pastor } 1989 \\
\text { Caballero } 1994 / 95\end{array}$ \\
\hline 58. Portera, La & $\begin{array}{l}\text { Visigodo, 2.a/s. VII } \\
\text { Visigodo o alta EM }\end{array}$ & Tipología & $\begin{array}{l}\text { Cerrillo } 1981 \\
\text { Caballero 2004a }\end{array}$ \\
\hline 19. Priesca & (921) Asturiano & Epigrafía & Arias 1993 \\
\hline 63. Pueblanueva & Tardo romano, s. IV & Excavación, estilo & Schlunk y Hauschild 1978 \\
\hline 45. Quintanilla & $\begin{array}{l}\text { Visigodo, fin vI, inicios vII } \\
\text { (929) Reconquista, s. x }\end{array}$ & $\begin{array}{l}\text { Estilo } \\
\text { Tipología }\end{array}$ & $\begin{array}{l}\text { Schlunk y Hauschild } 1978 \\
\text { Caballero 1994/95 }\end{array}$ \\
\hline 27. Santa Coloma & $\begin{array}{l}\text { Romano/mozárabe } \\
\text { (923) Mozárabe, s. x }\end{array}$ & $\begin{array}{l}\text { Tipología } \\
\text { Lectura }\end{array}$ & $\begin{array}{l}\text { López y Hernáez } 1998 \\
\text { Caballero } 2001\end{array}$ \\
\hline 57. Santa Olalla & $\begin{array}{l}\text { Visigodo, s. VII } \\
\text { ¿? }\end{array}$ & $\begin{array}{l}\text { Tipología } \\
\text { Decoración reutilizada }\end{array}$ & $\begin{array}{l}\text { Cerrillo } 1981 \\
\text { Caballero y Arce } 2004\end{array}$ \\
\hline 1. Santiago Compostela & (899) Asturiano & Documentación, tipología & Hauschild 1992 \\
\hline 10. Santullano & Asturiano, $1 . \mathrm{a} / 2 \mathrm{~s}$. IX & Documentación, tipología & Arias 1993 \\
\hline 40. Siero & (882) Reconquista & $\begin{array}{l}\text { Epigrafía } \\
\text { Tipología }\end{array}$ & $\begin{array}{l}\text { Caballero 1994/95 } \\
\text { Real } 1995\end{array}$ \\
\hline $\begin{array}{l}\text { 29. Suso/1 } \\
\text { Suso/2 } \\
\text { Suso/3 }\end{array}$ & $\begin{array}{l}\text { Visigodo o mozárabe } \\
\text { Mozárabe } \\
\text { Protorrománico }\end{array}$ & & $\begin{array}{l}\text { Gómez Moreno } 1919 \\
\text { Caballero 2004d }\end{array}$ \\
\hline $\begin{array}{l}\text { 23. Tobillas/1 } \\
\text { Tobillas/2 }\end{array}$ & $\begin{array}{l}\text { (822) Reconquista } \\
\text { (939) Reconquista }\end{array}$ & $\begin{array}{l}\text { Epigrafía, documentación, } \\
\text { excavación, estratigrafía, tipología }\end{array}$ & Azkarate 1995 \\
\hline 69. Tolmo, El & Tardo romano/alta EM, fin vI-VIII & Excavación & Abad y otros 2000 \\
\hline 59. Trampal, El & $\begin{array}{l}\text { Visigodo } \\
\text { 1.er mozárabe, circa } 800\end{array}$ & $\begin{array}{l}\text { Tipología } \\
\text { Excavac., estratigrf., tipolog. }\end{array}$ & $\begin{array}{l}\text { Arbeiter } 1996 \\
\text { Caballero y Sáez } 1999\end{array}$ \\
\hline 26. Tricio/1 y 2 & $\begin{array}{l}\text { Romano/Mozárabe } \\
\text { Reconquista, circa } 900\end{array}$ & $\begin{array}{l}\text { Excavación, estilo } \\
\text { Estratigrafía, tipología }\end{array}$ & $\begin{array}{l}\text { López y Hernáez } 1998 \\
\text { Caballero } 2001\end{array}$ \\
\hline 15. Tuñón & (891)Asturiano, 3.\%/3 s. Ix & Documentación, tipología & Arias 1993 \\
\hline 61. Valdecebadar & Visigodo, mediados VII & Excavación, estilo & Ulbert 1973 \\
\hline 18 Valdediós & (893) Asturiano & Epigrafía, tipología & Arias 1993 \\
\hline 67. Valencia, S. Vicente & Visigodo, s.viI & Excavación, tipología & Albiach y otros 2000 \\
\hline 37. Vilella & Mozárabe, s. x & Excavación, documentación (934) & Nozal y otros 1990 \\
\hline 28. Ventas Blancas & $\begin{array}{l}\text { Visigodo, 2.a/2 s. VII } \\
\text { Reconquista, circa } 900\end{array}$ & $\begin{array}{l}\text { Tipología } \\
\text { Tipología }\end{array}$ & $\begin{array}{l}\text { Schlunk y Hauschild } 1978 \\
\text { Caballero 1994/95 }\end{array}$ \\
\hline 24. Vitoria, catedral & Reconquista & Excavación & Azkarate 2001 \\
\hline 36. Wamba & Mozárabe, s. x & Tipología & Gómez Moreno 1919 \\
\hline 25. Zalduendo & $\begin{array}{l}\text { Reconquista, circa } 900 \\
\text { Románico, s. XI }\end{array}$ & $\begin{array}{l}\text { Tipología } \\
\text { Tipología }\end{array}$ & $\begin{array}{l}\text { Caballero } 2001 \\
\text { Arbeiter y otros } 1994\end{array}$ \\
\hline
\end{tabular}




\section{Bibliografía}

Abad Casal, L., Gutiérrez Lloret, S. y Gamo Parras, B., 2000, La basílica y el baptisterio del Tolmo de Minateda (Hellín, Albacete), Archivo Español de Arqueología 73, 193-221.

Aguiar Barreiros, C. M., 1934, A Igreja de S. Pedro de Lourosa. Porto.

Alba Calzado, M., 2001, Mérida. La islamización de Extremadura, en Cuadernos Emeritenses, 17, MNAR.

Id. y FeIJOO, S., 2003, Iglesia de los Santiagos, Alburquerque, en MATEOS, P. y Caballero, L. (eds.), Repertorio de Arquitectura Cristiana en Extremadura: Época Tardoantigua y Altomedieval: 11-14. Anejos de AEspa XXIX. Madrid.

Albiach, R.; Badía, À.; Calvo, M.; Marín, C.; Pí́, J. y Ribera, A., 2000, Las últimas excavaciones (1992-98) del solar de L'Almoina: nuevos datos de la zona episcopal de Valencia, V Reunión de Arqueología Cristiana Hispánica, 63-86. Cartagena 1998. Barcelona.

Alonso Matthías, F., Caballero Zoreda, L. y Rodríguez Trobajo, E., 1997, Cronología constructiva de la iglesia mozárabe de S. Baudelio de Berlanga (Soria): primeros resultados de dendrocronología y carbono-14, Boletín de Arqueología Medieval 11, 249-263.

Id., Rodríguez Trobajo, E y Rubinos Pérez, A., 2004, Datación de madera constructiva en San Pedro de La Nave (Zamora) y su interdatación con San Juan de Baños (Palencia), en Caballero, L. (coord.) 2004: 209-237.

Andrés OrdaX, S. y AbÁsolo, J. A., 1980, La ermita de Santa María. Quintanilla de las Viñas, Burgos. Burgos.

Aparicio, J. A. y Fuente, A. de la, 1996, Estudio arqueológico e intervención arquitectónica en la iglesia de la Asunción de San Vicente del Valle, Numantia 6, 153-172.

ARbeiter, A.; PÄffgen, B. y Karas, U., 1994, Die vor- und frühromanische Kirche San Julián y Santa Basilisa de Aistra bei Zalduendo (Álava), Madrider Mitteilungen 35, 418-439.

Id., 1995, Construcciones con sillares. El paulatino resurgimiento de una técnica edilicia en la Lusitania visigoda, IV Reunión de Arqueología Cristiana Hispánica, 211-221.

Id., 1996, Die Anfänge der Quaderarchitektur im westgotenzeitlichen Hispanien, en BrenK, B. (ed.), Innovation in der Spätantike, 11-52. Wiesbaden.

Id. y NoACK-Haley, S., 1999, Christliche Denkmäler des frühen Mittelalters vom 8. bis ins 11. Jahrhundert. Mainz am Rhein.

ARCE, F., 1998, Análisis arqueológico de la arquitectura en la iglesia de la Asunción, San Vicente del Valle (Burgos), I Congreso de Arqueología en Burgos (en prensa).

Id., 2001, La escultura arquitectónica altomedieval a la luz de la lectura de paramentos, V Congreso de Arqueología Medieval Española, 263-272. Valladolid 1999.

Arias Páramo, L. y AdÁn Álvarez, G., 1991, Iglesia prerrománica de San Julián de los Prados. Decoración figurativa inédita, Revista de Arqueología 122, 44-48.

Id., 1993, Prerrománico asturiano. El arte de la Monarquía Asturiana. Gijón.

Id., 2001, Fundamentos geométricos, metrológicos y sistemas de proporción en la arquitectura altomedieval asturiana (siglos VIII y X), Archivo Español de Arqueología 74, 233-280.

Id. s/a, Reconstrucción de la Iglesia de San Miguel de Liño, Liño 11, 9-47.

Azkarate Garai-Olaun, A., 1995, Aportaciones al debate sobre la arquitectura prerrománica peninsular: la iglesia de San Román de Tobillas (Álava), Archivo Español de Arqueología 68, 189-214.

Id., 2001, Análisis de la evolución histórico-constructiva de la catedral de Santa María de Vitoria-Gasteiz (Aplicación de la «Arqueología de la Arquitectura" a un modelo complejo), $V$ Congreso de Arqueología Medieval Española (Valladolid 1999), vol. 1, 177-212.

Id. y Quirós CASTILlo, J. A., 2001, Arquitectura doméstica altomedieval en la Península Ibérica. Reflexiones a partir de las excavaciones arqueológicas de la Catedral de Santa María de Vitori-Gasteiz, País Vasco, Archeologia Medievale XXVIII, 25-60.
AzUAR, R., 1995, Las técnicas constructivas en al-Andalus. El origen de la sillería y el hormigón de tapial, $V$ Semana de Estudios Medievales, $125-142$.

BARRAL, X., 1981, L'art pre-romànic a Catalunya. Segles IX-X. Barcelona. Berrocal Rangel, L. y Caso Amador, R., 1991, El conjunto monacal visigodo de San Miguel de los Fresnos (Fregenal de la Sierra, Badajoz): Estudio preliminar, Cuadernos de Prehistoria y Arqueología de la Universidad Autónoma de Madrid 18, 299-317.

Bonnet, C. y Beltrán de Heredia, J., 2001, Origen y evolución del conjunto episcopal de Barcino: de los primeros tiempos cristianos a la época visigótica, en BELTRÁN, J. (dir.), De Barcino a Barcinona (siglos I-VII). Los restos arqueológicos de la plaza del Rey de Barcelona, 74-93. Barcelona.

Caballero, L. y Latorre, P., 1982, Santa María de Melque y la arquitectura visigoda, II Reunión de Arqueología Cristiana Hispánica, 303-330.

Id. y CÁMARA, L., 1989, Símbolos de poder y religión en España tardorromana y visigoda (siglos $I V$-VII), Madrid.

Id., 1991, Observaciones sobre materiales y tecnologías de construcción de época visigoda en España y Portugal, MARINO, L. (ed.), Materiali da costruzione e tecniche edili antiche, 23-30.

Id., Galera, V. y GarRalDA, M. D., 1991, La iglesia de época paleocristiana y visigoda de "El Gatillo de Arriba» (Cáceres), Extremadura Arqueológica, 2, 471-497.

Id.; Latorre GonzÁlez-Moro, P. y Matesanz Vera, P., 1994, La iglesia prerrománica de San Pedro el Viejo (Hortigüela, Burgos), Numantia 5, 139-165.

Id., 1994/95, Un canal de transmisión de lo clásico en la Alta Edad Media Española. Arquitectura y Escultura de influjo omeya en la Península Ibérica entre mediados del siglo VIII e inicios del siglo X, al Qanta$r a, 15 / 2,321-348 ; 16 / 1,107-124$.

Id. y ARCE, F., 1997, La iglesia de San Pedro de La Nave (Zamora). Arqueología y Arquitectura, Archivo Español de Arqueología 70, 221-274.

Id. y FeIjOO, S., 1998, La iglesia altomedieval de San Juan Bautista en Baños de Cerrato (Palencia), Archivo Español de Arqueología 71, 181-242.

Id. y FERNÁNDEZ MieR, M., 1999, Notas sobre el complejo productivo de Melque (Toledo). Prospección del territorio y análisis de Carbono 14, polínicos, carpológicos y antracológicos y de morteros, Archivo Español de Arqueología 72, 199-239.

Id. y SÁEZ, F., 1999, La iglesia Mozárabe de Santa Lucía del Trampal, Alcuéscar (Cáceres). Arqueología y arquitectura, "Memorias de Arqueología Extremeña» 2. Mérida.

Id., 2001, Aportación a la arquitectura medieval española. Definición de un grupo de iglesias castellanas, riojanas y vascas, Actas del V Congreso de Arqueología Medieval Española (Valladolid 1999), vol. 1, 221-233.

Id.; Retuerce Velasco, M. y Sáez Lara, F., 2003, Las cerámicas del primer momento de Santa María de Melque (Toledo), construcción, uso y destrucción. Comparación con las de Santa Lucía del Trampal y El Gatillo (Cáceres), en Id., Mateos, P. y Retuerce, M. (eds.), Cerámicas tardorromanas y altomedievales en la Peninsula Ibérica. Ruptura y continuidad, "Anejos de AEspA», 225-273.

Id., 2004a, Arquitectura tardoantigua y alto medieval en Extremadura, en Mateos, P. y Caballero, L. (eds.), Repertorio de Arquitectura Cristiana en Extremadura, "Anejos de Archivo Español de Arqueología», 29, 143-176.

Id., 2004b, Excavaciones Arqueológicas en el lugar de Melque (San Martín de Montalbán, Toledo), en Investigaciones Arqueológicas en Castilla y La Mancha 1996-2002, 345-363.

Id., 2004c, La fecha de las grapas y el modelo explicativo post-visigodo de San Pedro de La Nave, en Caballero (coord.) 2004: 427-437.

Id., 2004d, La iglesia de San Millán de La Cogolla de Suso. Lectura de paramentos 2002, VIII Jornadas de Arte y Patrimonio Regional, Arte Medieval en La Rioja: Prerrománico y Románico (Logroño, 2002), «Actas IER», 13-93. 
Id., 2004e (coord.), La Iglesia de San Pedro de La Nave (Zamora). Instituto de Estudios Zamoranos, Zamora.

Id. y ARCE SAINZ, F., 2004, Producción decorativa y estratigrafía, III Simposio Arqueología Mérida. Escultura decorativa en Hispania tardo romana y alto medieval. CSIC. Consorcio de la Ciudad Monumental de Mérida. Junta de Extremadura, en CABALlero ZoredA, L. y Mateos CruZ, P. (edits.), «Anejos de AEspA» (en prensa).

Id.; ArCe SainZ, F. y Utrero Agudo, M. a A., 2004, La iglesia de San Torcuato de Santa Comba de Bande (Orense): arqueología de la arquitectura, Archivo Español de Arqueología 77, 273-318.

Id. y Murillo Fragero, J. I., 2005, Notas sobre las cercas y murallas de Santa María de Melque, en Espacios fortificados en la provincia de Toledo: Evolución y problemática en el sector central de la submeseta sur, Diputación de Toledo (2003), 255-291.

CÁNOVAS GuilléN, P. F., 2002, El material cerámico de construcción en época visigoda: la basílica del Tolmo de Minateda, Hellín, Albacete, II Congreso de Historia de Albacete, vol. I: Arqueología y Prehistoria, 293-300. Albacete, 2000.

CAstillo, A. del, 1975, La necrópolis de covachas artificiales del monasterio de Suso, pervivencia del sistema de enterramiento eremítico, XIII Congreso Nacional de Aruqeología, 967-978.

Cerrillo Martín de Cáceres, E., 1981, Las ermitas de Portera y Santa Olalla. Aproximación al estudio de las cabeceras rectangulares del siglo VII, Zephyrus 32-33, 233-243.

Corzo, R., 1978, Génesis y función del arco de herradura, al-Andalus 43, 125-142.

Id., 1986, San Pedro de La Nave. Estudio histórico y arqueológico de la iglesia visigoda. Zamora.

Chamoso Lamas, M., 1952, Sobre el origen del monumento soterrado de Santa Eulalia de Bóveda (Lugo), Cuadernos de Estudios Gallegos XXII, 231-251.

Domínguez Perela, E., 1992, Capiteles hispánicos altomedievales. Las contradicciones de la cultura mozárabe y el núcleo bizantino del noroeste, Archivo Español de Arqueología, 223-262.

EsBERT, R. M. y otros 1992, El proceso digital de imágenes aplicado a la conservación de la piedra monumental. Un ejemplo: Santa María del Naranco, Revista de Arqueología 139, 7-11.

Escudero Ruiz, A., 1942-43, Una iglesia mozárabe en Hérmedes de Cerrato (Palencia), Boletín del Seminario de Estudios de Arte y Arqueología de la Universidad de Valladolid 9, 183-185.

Fernández Galiano, D.; Piraccini, C.; Miranda, J. L. y De Luna, I., 2001, La más antigua basílica cristiana de Hispania, Carranque. Centro de Hispania romana, 71-80. Alcalá de Henares, Catálogo del Museo Arqueológico Regional.

Fernández Mier, M. y Quirós CAstillo, J. A., 2001, La evolución de las técnicas constructivas en Asturias en la Edad Media, V Congreso de Arqueología Medieval Española 1, 371-382.

Ferreira de Almeida, C. A., 1986, História da Arte em Portugal. Arte da Alta Idade Média, Lisboa.

Gómez Moreno, M., 1919, Iglesias Mozárabes. Arte español de los siglos IX al XI. Madrid.

Id., 1927, Catálogo Monumental de España. Provincia de Zamora (1903-05). Madrid.

Id., 1949, Miscelánea. Historia-Arte-Arqueología (dispersa, emendata, addita, inedita). 1.a serie: La Antigüedad. Madrid.

Id., 1951, Arte mozárabe, Ars Hispaniae III, 355-409. Madrid.

HAuschild, Th., 1968, La iglesia martirial de Marialba (León), Boletín de la Real Academía de la Historia CLXIII/II, 243-249.

Id., 1969, Das Mausoleum bei Las Vegas de Pueblanueva (Toledo), Madrider Mitteilungen 10, 296-316.

Id., 1972, Westgotische Quaderbauten des 7. Jhs. auf der Iberischen Halbinsel, Madrider Mitteilungen 13, 270-285.

Id., 1982, Técnicas y maneras de construir en la arquitectura paleocristiana hispánica, II Reunión de Arqueología Cristiana Hispánica, 71-86.
Id., 1992, The Archaeology and the Tomb of St. James, Williams, J. (ed.), The Codex Calistinus and the Shrine of St. James, 89-103.

Id., 1996, Orientalische Tendenzen in der Architektur des westgotischen Herrschaft in der Hispania, Spanien und der Orient im frühen und hohen Mittelalter (Kolloqium Berlin, 1991), Madrider Beiträge 24, 1-8.

Heras, E.; Escribano, C. y Balado, A., 2001, San Miguel de Gormaz (Soria). Estudio y puesta en valor de un edificio histórico, $V$ Congreso de Arqueología Medieval Española, t. 1, 393-405. Valladolid 1999.

HernándeZ, F., 1928, La techumbre de la Gran Mezquita de Córdoba, Archivo Español de Arte y Arqueología 4, 191-225.

Id., 1975, El Alminar de 'Abd Al-Rahman III en la Mezquita Mayor de Córdoba. Génesis y repercusiones. Granada.

JiMÉNEZ, A., 1982, Relaciones métricas en Arquitectura. Análisis de tres propuestas, Homenaje a Sáenz de Buruaga, 427-438.

JuAn, E. y PASTOR, I., 1989, Los visigodos en Valencia. Pla de Nadal: ¿una villa áulica?, Boletín de Arqueología Medieval 3, 137-179.

Kingsley, K., 1979, Visigothic architecture in Spain and Portugal: a study in masonry, documents and form. Univ. Berkeley.

LECANDA, J. A., 1999, Mijangos: arquitectura y ocupación visigoda en el Norte de Burgos, II Congreso de Arqueología Peninsular, 415-434.

López Domech, R. y Hernáez Urraca, J., 1998, El Martirium de Santa Coloma (La Rioja), Antigüedad y Cristianismo XV, 515-540.

ManZANo Moreno, E., 1991, La frontera de al-Andalus en época de los omeyas, Madrid.

MarfIL, P., 1998, Trabajos de investigación arqueológica en las cúpulas de la maqsura de la Mezquita de Córdoba; Nuevos datos para el conocimiento del lucernario de al-Hakam II en la Capilla de Villaviciosa de la Mezquita de Córdoba, Qurtuba 3, 250-253.

Mateos, P. y Alba, M., 2000, De Emerita Augusta a Marida, Visigodos y Omeyas, 143-168.

Mergelina, C., 1947, El sepulcro de La Alberca, III Congreso Arqueológico del Sudeste Español, 283-293. Murcia.

NOACK-Haley, S., 1986, Westgotenzeitliche Kapitelle im Duero-Gebiet und in Asturien, Madrider Mitteilungen 27, 389-409.

Id., 1992, Tradición e innovación en la decoración plástica de los edificios reales asturianos, III Congreso de Arqueología Medieval Española, t. II, 174-184. Oviedo 1989.

Id., 1995, Beobachtungen zu Ästhetik und Ikonographie an der asturischen Königsbasilika San Julián de los Prados (Oviedo); Madrider Mitteilungen 36, 336-343.

Nozal, M.; Guerra, J. L.; De la Cruz, A. y Barcenilla, A., 1990, Iglesia prerrománica en Villella. Antigüedad (Palencia), II Congreso de Historia de Palencia, t. I, 509-523. Palencia, 1989.

Núñez Rodríguez, M., 1978, Historia da Arquitectura Galega. Arquitectura Prerromanica. Madrid.

Osaba y Ruiz De ERenchun, B., (1968-72), Últimas novedades arqueológicas de la provincia de Burgos. III. La ermita visigoda de Barbadillo del Mercado, Revista de Archivos, Bibliotecas y Museos LXXV, 579-582.

Palol i Salellas, P., 1967, Arqueología Cristiana de la España romana. Madrid-Valladolid.

Puertas Tricas, R., 1979, La iglesia rupestre de Las Mesas de Villaverde (Ardales, Málaga), Mainake I, 179-204.

Quirós CASTILLO, J. A., 1998, La sillería y las técnicas constructivas medievales: historia social y técnica de la producción arquitectónica, $\mathrm{Ar}$ cheologia Medievale XXV, 235-246.

REAL, M. L., 1995, Inovação e resistência: dados recentes sobre a antiguidade cristã no ocidente peninsular, IV Reunión de Arqueología Cristiana Hispánica, 17-68. Lisboa, 1992. Barcelona.

Ribera, A. y Roselló, M., 2000, El primer grupo episcopal de Valencia, Los orígenes del Cristianismo en Valencia y su entorno, 165-185. Valencia.

Rodríguez Trobajo, E., Alonso Matthias, F. y Caballero ZoreDA, L., 1998, Datación de una viga de la iglesia de San Pedro de La Nave, Archivo Español de Arqueología 71, 283-294. 
Id., 2000, Dendrocronometría de maderas altomedievales en la Península Ibérica. S. Baudelio de Berlanga (Soria), Actas do 3. ${ }^{\text {er }}$ Congresso de Arqueologia Peninsular, Porto, vol. IX, 223-238.

Roselló Mesquida, M. y Soriano Sánchez, R., 1998, Los restos arqueológicos exhibidos, Cripta Arqueológica de la Cárcel de San Vicente, 41-56. Valencia.

SÁEnZ Preciado, M. ${ }^{a}$ P., 1999, Últimas actuaciones realizadas en la ermita de Nuestra Señora de los Arcos (Tricio, La Rioja), Estrato X, 11-19.

SCHLUNK, H. y HAusCHILD, T., 1962, Informe preliminar sobre los trabajos realizados en Centcelles. Excavaciones Arqueológicas en España 18.

Id., 1978, Die Denkmäler der frühchristlichen und westgotischen Zeit. Mainz am Rhein.

TORRES BALBÁS, L., 1936, La reparación de la techumbre de la mezquita de Córdoba en el siglo XIII, al-Andalus 4, 171-173.

UlberT, T., 1973, Die westgotenzeitliche Kirche von Valdecebadar bei Olivenza (Prov. Badajoz), Madrider Mitteilungen 14, 202-216.
Unzueta, M. y MarTíneZ, A., 1994, Proyecto de variante y túnel entre las Conchas de Haro y el cruce de Briñas. Yacimiento de Castro de Buradón, Arqueología de Urgencia en Álava 1989-1993, 43-60. Vitoria.

Utrero Agudo, M. a A., 2004, Iglesias Tardoantiguas y Altomedievales en la Península Ibérica. Análisis Arqueológico y Sistemas de Abovedamiento. Tesis doctoral, Universidad Autónoma de Madrid, Departamento de Prehistoria y Arqueología (manuscrito).

VVAA, 1999, Ideologie e pratiche del reimpiego nell'Alto Medioevo, XLVI Settimane di Studio del Centro Italiano sull'Alto Medioevo. Spoleto.

Vigil-EsCALERA GUIRADO, A., 2000, Cabañas de época visigoda: evidencias arqueológicas del sur de Madrid. Tipología, elementos de datación y discusión, Archivo Español de Arqueología 73, 223-252.

WARD-Perkins, J. B., 1971, Quarries and Stoneworking in the Early Middle Ages: the heritage of the Ancient World, XVIII Settimane di Studio del Centro Italiano sull'Alto Medioevo, 525-544.

ZOZAYA, J., 1976, Algunas observaciones en torno a la ermita de San Baudelio de Casillas de Berlanga, Cuadernos de la Alhambra 12, 307-338. 